\title{
Selecting Bacterial Antagonists for Cucurbit Downy Mildew and Developing an Effective Application Method
}

\begin{abstract}
Li Zheng, Jiangsu Key Laboratory for Eco-Agricultural Biotechnology around Hongze Lake, School of Life Science, Huai'an Normal University, Huai' an 223300, China; Department of Plant Pathology, College of Plant Protection, Nanjing Agricultural University; Jiangsu Provincial Biogenic Pesticide Engineering Center; Key Laboratory of Integrated Management of Crop Diseases and Pests, Nanjing Agricultural University, Ministry of Education; Nanjing 210095, China; and Chinese Academy of Tropical Agricultural Sciences Guangzhou Experimental Station; Guangzhou 510140, China; Chun Gu, Jiangsu Provincial Anfeng Biogenic Pesticide Engineering Center Co., Ltd., Taicang 215400, China; Jing Cao, Department of Plant Pathology, College of Plant Protection, Nanjing Agricultural University; Jiangsu Provincial Biogenic Pesticide Engineering Center; and Key Laboratory of Integrated Management of Crop Diseases and Pests, Nanjing Agricultural University; Shi-mo Li, Jiangsu Key Laboratory for Eco-Agricultural Biotechnology around Hongze Lake, Huai' an Normal University; Guang Wang, Jiangsu Provincial Anfeng Biogenic Pesticide Engineering Center Co., Ltd.; Yu-ming Luo, ${ }^{\dagger}$ Jiangsu Key Laboratory for Eco-Agricultural Biotechnology around Hongze Lake, Huai' an Normal University; and Jian-hua Guo, ${ }^{\dagger}$ Jiangsu Provincial Anfeng Biogenic Pesticide Engineering Center Co., Ltd.; Department of Plant Pathology, College of Plant Protection, Nanjing Agricultural University; Jiangsu Provincial Biogenic Pesticide Engineering Center; and Key Laboratory of Integrated Management of Crop Diseases and Pests, Nanjing Agricultural University
\end{abstract}

\begin{abstract}
To identify new bacterial antagonists for cucurbit downy mildew (CDM) caused by Pseudoperonospora cubensis, 163 bacterial isolates were recovered from different microenvironments of field-grown cucumber plants. In the greenhouse, 19 representative isolates were applied to cucumber plants as a foliar spray (FS); 7 isolates achieved the efficacy over $60 \%$ against CDM, with 5 (DS22, HS10, DP14, HP4, and DS57) identified as Bacillus pumilus, B. licheniformis, Enterobacter sp., Bacillus sp., and Stenotrophomonas maltophilia, respectively. Strains DP14, DS22, and HS10 were assessed for their biocontrol effect on naturally occurring CDM in 2-year field trials (2010 and 2011), in which their overall efficacy

relative to that of propamocarb was 106.25 to $117.17 \%$ with foliar spray plus root drench (FS+RD) but only 70.98 to $84.03 \%$ with FS. Coincidently, DP14 and HS10 applied as root drench (RD) alone also significantly reduced CDM. Under field conditions, DP14, DS22, and HS10 all successfully colonized cucumber leaves and the rhizosphere, and also significantly increased fruit yield by 37.60 to $51.03 \%$, as well as nutrient levels. Taken together, Enterobacter sp. DP14, B. licheniformis HS10, and B. pumilus DS22 are plant-growth-promoting rhizobacteria effective in controlling CDM in the field, whose efficacy increased with FS+RD compared with FS alone.
\end{abstract}

Cucumber (Cucums sativus L.) is among the top 10 cultivated vegetables worldwide. Cucumber production has been severely affected by cucurbit downy mildew (CDM) caused by the oomycete Pseudoperonospora cubensis. This devastating foliar disease is favored by warm and humid weather conditions and has occurred in more than 70 countries (Cohen and Reuveni 1983). To date, its control has mainly relied on resistant cultivars and chemical fungicides (Call et al. 2013). However, $P$. cubensis has evolved the ability to rapidly overcome genetic host resistance (Cohen et al. 2015), leading to CDM still occurring on resistant cultivars (Call et al. 2013). On the other hand, the pathogen has also developed resistance to some fungicides, such as metalaxyl-resistance first reported in the 1970s (Cohen and Reuveni 1983); in addition, the long-term use of chemical fungicides threatens human health and the environment owing to their toxic

${ }^{\dagger}$ Corresponding authors: Y.-m. Luo; E-mail: yumingluo@163.com; and J.-h.Guo; E-mail: jhguo@njau.edu.cn

L. Zheng and C. Gu contributed equally to this study and are regarded as joint first authors.

This study was financially supported by National Natural Science Foundation of China (31470100); the Science and Technology Project of Suzhou Municipal Science and Technology Bureau (SNG201232), Suzhou City, Jiangsu Province, China; the Natural Science Foundation of Hainan Province (20153128); and the Key Science Research Project of Jiangsu Province research and development of microbial pesticide for soilborne disease on Solanaceae vegetables (BE201531032).

*The $\boldsymbol{e}$-Xtra logo stands for "electronic extra" and indicates that one supplementary figure and two supplementary tables are published online.

Accepted for publication 20 October 2017.

This article is in the public domain and not copyrightable. It may be freely reprinted with customary crediting of the source. The American Phytopathological Society, 2018. residues. Therefore, the management of CDM relying on resistant cultivars and fungicides is still far from satisfactory in terms of their effectiveness and impact on the environment.

Resolving these issues calls for more environmentally friendly approaches to its management. During the past few decades, biological control of plant diseases has proven to be effective on a variety of plant species (Reuveni 1983). Various biological control agents (BCAs) showed the capacity to suppress CDM to varying degrees. They comprised plant extracts (Harish et al. 2008), compost extracts (Winterscheidt et al. 1990), beneficial microorganisms and microbial toxins (Koch 1999), harpin proteins (Keinath et al. 2007), and volatile organic compounds (VOC) produced by Bacillus subtilis and B. amyloliquefaciens such as the growth-promoting VOC $(2 \mathrm{R}, 3 \mathrm{R})$ (-)-butanediol (Ryu et al. 2004). Using bacterial antagonists to control $P$. cubensis has become a research hotspot, with several bacterial strains identified as potential BCAs against CDM, including Streptomyces sp. YCXU (Faheem et al. 2015), B. licheniformis AE6 (Sen et al. 2014), B. pumilus (El-Gremi et al. 2013), Enterobacter sp. (Georgieva and Georgiev 2009), and nonpathogenic Fusarium oxysporum Fo-B2 (Shishido et al. 2005). Their modes of action include antibiosis (producing antibiotics, toxins, and biosurfactants), secretion of extracellular hydrolytic enzymes (protease, cellulase, chitinase, and glucanase) and siderophores, competition for nutrition and space by colonization, and activation of plant systemic resistance such as rhizobacterium-mediated induced systemic resistance (ISR) in host plants (Alabouvette et al. 2009; Dahiya et al. 2005; Haas and Keel 2003). To date, some bacterial antagonists have served as active ingredients of commercialized BCAs against $\mathrm{CDM}$, with $B$. subtilis strain QST713 included in Serenade (AgraQuest) and B. licheniformis strain BL-6 registered as a fungicide for this disease in China (Yang et al. 1994). However, the performance of the commercially available BCAs varies under different soil and climate conditions, which necessitates continuous identification of new bacterial antagonists and development of effective application methods. 
The objectives of this study were to (i) isolate bacteria from fieldgrown cucumber plants and characterize all isolates in genetic diversity and the ability to produce extracellular hydrolytic enzymes and secondary metabolites, (ii) evaluate selected bacteria for their in vitro antagonism and biocontrol efficacy against CDM and plant-growthpromoting effect in the greenhouse and field, (iii) to assess the leafand root-colonizing ability of selected antagonistic bacteria in the field, and (iv) to develop an effective application method.

\section{Materials and Methods}

Sample collection. In November 2009, cucumber plants and bulk soil were sampled using the five-point sampling method from a P. cubensis-infested field located in Yangzhou City, Jiangsu Province. The field comprised five plots of about $120 \mathrm{~m}^{2}$ each, having coarse sandy loam. Both diseased and healthy plants with tightly adherent rhizosphere soil were sampled, and each bulk soil sample was taken from the soil layer 0 to $15 \mathrm{~cm}$ in depth within a $1-\mathrm{m}^{2}$ area surrounding a plant sample (Morris et al. 1997). All samples were immediately placed into sterile plastic bags and sealed, then transported to the laboratory and processed in $24 \mathrm{~h}$

Isolation of bacteria from different cucumber microenvironments. Bacteria were isolated from the leaf interior and phyllosphere of cucumber plants, as described by Yang et al. (2008). For isolating soilassociated bacteria, five rhizosphere samples and five bulk soil samples collected from the same plot were pooled, mixed, and sieved with a 2-mm mesh, and subsequently suspended in a sterile $0.85 \% \mathrm{NaCl}$ solution in the ratio of 1:9 ( $\mathrm{vol} / \mathrm{vol})$ in a sterilized Erlenmeyer flask, which was incubated at $25^{\circ} \mathrm{C}$ with shaking at $180 \mathrm{rpm}$ for $30 \mathrm{~min}$, then settled for $10 \mathrm{~min}$. The resulting supernatant was dilution-plated on $\mathrm{R}_{2} \mathrm{~A}$ agar as described by Yang et al. (2008). The bacteria isolated from the serially diluted soil samples were quantified by counting colonies on plates after incubation at $28^{\circ} \mathrm{C}$ for about $72 \mathrm{~h}$.

Detection of extracellular hydrolytic enzymes and siderophores. All of the obtained 163 bacterial isolates were examined for their ability to produce extracellular hydrolytic enzymes and siderophores. Protease activity, indicated by casein degradation, was determined based on the widths of clear zones around colonies grown on skimmed milk agar, as reported by Yang et al. (2008). Cellulase activity was detected using the method of Ghose (1987); chitinase activity was evaluated based on the widths of clear zones around colonies grown on chitin-agar plates according to Roberts and Selitrennikoff (1988). Siderophore production was detected as reported by Shin et al. (2001). In these assays, each isolate was tested in four replicate plates, and each plate consisted of 3 inoculation replicates, leading to a total of 12 replicates per isolate in each assay.

BOX-polymerase chain reaction fingerprint analysis. All of the 163 bacterial isolates were subjected to BOX polymerase chain reaction (PCR) using the method reported by Yang et al. (2011). In brief, genomic DNA was extracted from each isolate and purified using a Mini BEST Bacterial Genomic DNA Extraction kit (Shanghai SBS Genetech Co. Ltd.). BOX-PCR was performed using the BOXA1R primer, as described by Rademaker and De Bruijn (1997). With a DNA Engine PTC-200 thermal cycler (Bio-Rad), amplification was performed under the cycling conditions reported by Yang et al. (2011). PCR products were separated on a $1.5 \%$ agarose gel by electrophoresis. BOX-PCR-generated fingerprints were evaluated using GelComparII software (version 4.5; Applied Maths), the banding patterns were analyzed with Pearson correlation applied to the densitometric curves formed by the fingerprints, and clustering analysis was performed by means of the unweighted pair-grouping method based on arithmetic averages.

Examination of 19 representative isolates for in vitro antagonism and biocontrol efficacy in the greenhouse. Following the method of Berg et al. (2001), a dual-culture assay was conducted to detect the in vitro antagonism of 19 representative bacterial isolates against three pathogens: the oomycetes Phytophthora capsici isolate P14 and Pythium ultimum isolate C25 and the fungus Rhizoctonia solani isolate R23 (from Biological Pesticides and Green Plant Protection Laboratory of Nanjing Agriculture University). The selection of these three pathogens for testing the in vitro antagonism of 19 isolates was based on the following reasons: $P$. capsici and P. ultimum both have a close evolutionary relationship with $P$. cubensis, and $R$. solani and $P$. cubensis may have the semblable pathogenesis mechanism of producing pathogenic toxins and pathogenic enzymes such as cellwall-degrading enzymes; moreover, selecting $R$. solani was also due to our interest in biocontrol of sheath blight of rice in addition to $\mathrm{CDM}$, which is mentioned in the discussion section. Aliquots $(8 \mu \mathrm{l})$ from an overnight culture of a selected bacterial isolate grown in Luria-Bertani (LB) broth were spotted $2.7 \mathrm{~cm}$ from the center of a 9.0-cm potato dextrose agar (PDA) plate and allowed to soak into the agar, and a $0.5-\mathrm{cm}$ plug from the leading edge of a culture of a tested pathogen grown for 5 days at $28^{\circ} \mathrm{C}$ on PDA medium was placed in the center of the plate. Each plate consisted of 3 inoculation replicates of an isolate and a noninoculated control (LB broth), and each isolate was tested in four replicate plates, leading to a total of 12 inoculation replicates per isolate. Plates were incubated at $28^{\circ} \mathrm{C}$ and scored after 7 days by measuring the distance between the edges of the bacterial colony and the fungal mycelium.

Subsequently, the 19 isolates were examined for their efficacy in controlling CDM in the greenhouse with cucumber cultivar Jinyou35, provided by Tang Jing-yan (Institute of Vegetable Research, Huai' an City, Jiangsu Province). This cultivar was used throughout this study, except in a repeat experiment of colonization as indicated below. Seeds were surface sterilized as described by Guo et al. (2004), then sown in trays filled with potting soil (provided by Institute of Vegetable Research, Huai'an City, Jiangsu Province), which had organic matter content 65 to $75 \%$ and $\mathrm{pH}$ 6.0. Seedlings at the three-leaf stage were transplanted to pots $(12.8 \mathrm{~cm}$ in top diameter, $9.3 \mathrm{~cm}$ in bottom diameter, and $11 \mathrm{~cm}$ in height) filled with potting soil, which were incubated in a greenhouse maintained at $28^{\circ} \mathrm{C}$, with the relative humidity of 85 to $90 \%$ (Haggag 2002) and cycle of $16 \mathrm{~h}$ of light and $8 \mathrm{~h}$ of darkness per day.

To prepare inoculants, bacteria were grown in $\mathrm{LB}$ broth at $32^{\circ} \mathrm{C}$ with shaking at $200 \mathrm{rpm}$ for $48 \mathrm{~h}$. The resulting bacterial cell suspension was adjusted to $10^{8} \mathrm{CFU} / \mathrm{ml}$ with sterile water and supplemented with Tween-20 at a final concentration of $0.01 \%$ prior to use, and the concentration of the bacterial cell suspension was determined by plating in conjunction with measuring its optical density using a spectrophotometer at $600 \mathrm{~nm}$. The pathogen $P$. cubensis was from cucumber leaves with typical symptoms of CDM in a field in Huai' an City. The obtained isolates were observed under the electron microscope, and their mycelium, sporangiophore, and sporangium had the same morphological characteristics as those of $P$. cubensis recorded in literature. Therefore, the isolated pathogen was identified as $P$. cubensis, and isolate PC5 of it was then propagated as described by Okuno et al. (1991).

Nineteen isolates were selected for a greenhouse experiment to evaluate their efficacy against $P$. cubensis. Selection was based on the following factors. First, they represented isolates from all six sampled microenvironments, with 9 from mixed rhizosphere and surrounding bulk soils of diseased plants (DS), 4 from mixed rhizosphere and surrounding bulk soils of healthy plants (HS), 1 from the phyllosphere of diseased plants (DP), 1 from the phyllosphere of healthy plants (HP), 1 from the leaf interior of diseased plants (DI), and 3 from the leaf interior of healthy plants (HI) (Table 1). Second, they had the ability to produce extracellular hydrolytic enzymes and/or siderophores, with 14 producing protease, 9 expressing chitinase, 10 secreting cellulase, and 14 producing siderophores (Table 1). Third, they had relatively high genetic diversity, representing 19 distinct species belonging to 12 groups in BOX-PCR fingerprint analysis (Supplementary Table S2). In addition to the 19 bacterial treatments, the greenhouse experiment also involved a nontreated control, and fungicide controls 1 and 2, which were 0.2 and $0.02 \%$ of propamocarb, respectively, diluted from a $20 \%$ aqueous solution of propamocarb (Qingdao Dongsheng Pharmaceutical Co., Ltd.). Each treatment comprised four replicates of 14 cucumber plants each. Different treatments were arranged in a randomized complete block design. Plants at the 10leaf stage were treated with bacteria as a foliar spray (FS) as follows: leaves of each plant were sprayed with about $30 \mathrm{ml}$ of a bacterial cell suspension at $10^{8} \mathrm{CFU} / \mathrm{ml}, 0.2$ or $0.02 \%$ propamocarb, or water (the nontreated control). Five days later, leaves of each plant in each treatment were challenged by FS with $20 \mathrm{ml}$ of a $P$. cubensis suspension at $1 \times 10^{5}$ sporangium $/ \mathrm{ml}$. Disease severity ratings were recorded at 15 days post pathogen inoculation (dpi) according to a rating system 
with the following disease indexes: $0,1,3,5,7$, and 9 representing $0,<5,6$ to 10,11 to 25,26 to 50 , and $>50 \%$ leaf area with symptoms, respectively. Disease severity was calculated according to the following formula (Reuveni 1983): Disease severity $(\%)=\left[\sum\right.$ (number of symptomatic leaves in this index $)] \times$ disease index $] /[$ (total number of leaves investigated) $\times$ (hightest disease index $] \times 100$.

Five isolates (DP14, DS22, HS10, HP4, and DS57), which were selected for the biocontrol field trial in 2010 as depicted below, were subjected to molecular identification. Their genomic DNA was extracted as described above, then used in PCR to amplify approximately 1,500-bp conserved regions of $16 \mathrm{~S}$ ribosomal DNA (rDNA) sequences following the protocol of Yang et al. (2008). The isolates were identified by comparing the sequences of their $16 \mathrm{~S}$ rDNA conserved regions with those in the Nucleotide Sequence Database of National Center for Biotechnology Information (NCBI) with the Basic Local Alignment Search Tool.

Biocontrol assays in the field. The biocontrol efficacy of selected strains against CDM was assessed during two successive growing seasons (fall 2010 and spring 2011) in a large plastic tent in Huai' an City which had been subjected to 15 years of consecutive cucumber monoculture. The plot was about $480 \mathrm{~m}^{2}$ (10 by $\left.48 \mathrm{~m}\right)$, with light loamy soil, organic matter content of 1.8 to $1.9 \%$, and $\mathrm{pH} 6.5$. The two field trials, hereafter referred to as FT 2010 and FT 2011, both relied on natural disease infestation.

In FT 2010, surface-sterilized seeds were sown in a seedling bed within the plastic tent. The seedling bed was uncovered in the daytime but covered with a plastic film at night, in which temperature was 25 to $28^{\circ} \mathrm{C}$ in the daytime and at 18 to $20^{\circ} \mathrm{C}$ at night, with relative humidity about 80 to $95 \%$. Cucumber seedlings were grafted on figleaf gourd (Cucurbita ficifolia) using the approach grafting method in the seedling bed. At about 30 days after planting (DAP), seedlings were transplanted into the ground in the same plastic tent, and the ground was covered with black plastic mulch. Organic fertilizers were applied to the field at a rate of 1/6 ton/acre 1 month before seedling transplant, without additional fertilization later. After transplant, the plastic tent was covered with a retractable heat conservation curtain made of straw for reducing heat losses at nighttime; in the tent, the temperature was at 32 to $38^{\circ} \mathrm{C}$ in the daytime and at 20 to $25^{\circ} \mathrm{C}$ at night, and relative humidity remained at about 80 to $95 \%$. These parameters were monitored by an automatic temperature and humidity meter (Hefei) Plants were watered about every 3 or 5 days.

At about 50 DAP, cucumber seedlings were bacterially treated in three sets of treatments; each set consisted of five bacterial treatments (DP14, DS22, HS10, HP4, and DS57), a propamocarb control, and a nontreated control, with four replications per treatment and 25 seedlings per replication. Selection of these five strains for FT 2010 to assess their efficacy against CDM was based on their relatively high biocontrol efficacy $(>60 \%)$ in the greenhouse and rich taxonomic diversity, falling into four different BOX-PCR groups: G12 (DP14), G21 (DS57), G26 (DS22, HP4), and G29 (HS10). Different treatments were arranged in a randomized complete block design. Bacterial cell suspensions at $10^{7} \mathrm{CFU} / \mathrm{ml}, 0.02 \%$ aqueous solution of propamocarb (fungicide control), or water (the nontreated control) were applied to plants as FS (30 ml/plant) in set 1, as FS plus root drench (FS+RD) in set $2(30 \mathrm{ml}$ of the suspension was sprayed onto the leaves and the same volume was poured into the soil at the base of each seedling at the same time), and as root drench (RD) in set 3 (30 ml/plant). Plants were treated three times at 10-day intervals. CDM occurred naturally and disease severity ratings were recorded at 8,15 , and 22 days post first bacterial treatment (dpt) according to the same rating system as that for the previous greenhouse biocontrol assay.

FT 2011 followed the same protocol as FT 2010, except involving only two sets of treatments; each set was composed of three bacterial

Table 1. In vitro antagonism, characteristics, and greenhouse efficacy of 19 representative isolates

\begin{tabular}{|c|c|c|c|c|c|c|c|c|c|c|}
\hline \multirow[b]{2}{*}{ Treatment } & \multirow[b]{2}{*}{ ARDRA group } & \multicolumn{3}{|c|}{$\begin{array}{c}\text { In vitro } \\
\text { antagonism } \\
\text { against } \\
\text { pathogens }\end{array}$} & \multicolumn{4}{|c|}{ Production of enzymes and siderophores ${ }^{x}$} & \multirow[b]{2}{*}{ Disease severity $(\%)^{y}$} & \multirow[b]{2}{*}{ Biocontrol efficacy (\%) } \\
\hline & & Rs & $\mathbf{P u}$ & $\mathbf{P c}$ & Protease & Chitinase & Cellulase & Siderophores & & \\
\hline DS22 & G26 & - & - & - & ++ & - & ++ & + & $0.89 \pm 0.00 \mathrm{~b}$ & 87.81 \\
\hline DP14 & G12 & - & + & - & - & + & - & - & $2.14 \pm 0.94 \mathrm{ab}$ & 70.66 \\
\hline HP4 & G26 & - & - & - & ++ & - & ++ & - & $2.68 \pm 0.97 \mathrm{ab}$ & 63.31 \\
\hline HS10 & G29 & - & - & + & + & ++ & ++ & + & $2.78 \pm 1.39 \mathrm{ab}$ & 61.96 \\
\hline HS15 & G25 & + & + & + & +++ & - & ++ & ++ & $2.81 \pm 0.85 \mathrm{ab}$ & 61.49 \\
\hline DS57 & G21 & - & - & - & ++ & +++ & - & - & $2.89 \pm 1.70 \mathrm{ab}$ & 60.49 \\
\hline HS7 & G5 & + & - & - & ++ & ++ & - & + & $3.09 \pm 3.09 \mathrm{ab}$ & 57.72 \\
\hline DS59 & G9 & + & - & - & + & - & - & + & $3.48 \pm 1.51 \mathrm{ab}$ & 52.33 \\
\hline DS79 & G9 & - & - & ++ & - & - & ++ & + & $3.49 \pm 2.56 \mathrm{ab}$ & 52.12 \\
\hline DS19 & G5 & - & - & - & ++ & - & - & + & $3.73 \pm 3.73 \mathrm{ab}$ & 48.95 \\
\hline HS16 & G3 & - & - & - & - & + & - & + & $3.87 \pm 1.56 \mathrm{ab}$ & 46.97 \\
\hline DS44 & G5 & - & - & - & ++ & +++ & - & + & $3.98 \pm 1.50 \mathrm{ab}$ & 45.47 \\
\hline DS72 & G19 & - & - & - & ++ & +++ & - & - & $4.11 \pm 0.54 \mathrm{ab}$ & 43.63 \\
\hline HI1 & G5 & ++ & - & - & +++ & + & + & + & $4.15 \pm 2.42 \mathrm{ab}$ & 43.20 \\
\hline DS58 & G24 & + & - & - & +++ & - & ++ & - & $4.46 \pm 2.10 \mathrm{ab}$ & 38.90 \\
\hline DI1 & G8 & + & + & ++ & ++ & - & ++ & ++ & $4.65 \pm 3.15 \mathrm{ab}$ & 36.25 \\
\hline HI4 & G10 & - & - & - & - & - & - & + & $4.70 \pm 0.67 \mathrm{ab}$ & 35.61 \\
\hline DS67 & G3 & - & - & - & - & ++ & + & + & $4.72 \pm 2.84 \mathrm{ab}$ & 35.36 \\
\hline HI2 & G25 & + & + & + & ++ & - & +++ & ++ & $5.09 \pm 3.35 \mathrm{ab}$ & 30.28 \\
\hline Fungicide- $1^{\mathrm{z}}$ & $\ldots$ & $\ldots$ & $\ldots$ & $\ldots$ & $\ldots$ & $\ldots$ & $\ldots$ & $\ldots$ & $1.62 \pm 1.62 \mathrm{~b}$ & 77.75 \\
\hline Fungicide- $2^{\mathrm{z}}$ & $\ldots$ & $\ldots$ & $\ldots$ & $\ldots$ & $\ldots$ & $\ldots$ & $\ldots$ & $\ldots$ & $1.93 \pm 1.32 b$ & 73.50 \\
\hline Control & $\ldots$ & $\ldots$ & $\ldots$ & $\ldots$ & $\ldots$ & $\ldots$ & $\ldots$ & $\ldots$ & $7.30 \pm 4.08 \mathrm{a}$ & $\ldots$ \\
\hline$P$ value & $\ldots$ & $\ldots$ & $\ldots$ & $\ldots$ & $\ldots$ & $\ldots$ & $\ldots$ & $\ldots$ & 0.9433 & $\ldots$ \\
\hline
\end{tabular}


treatments (DP14, DS22, and HS10), a propamocarb control, and a nontreated control, with four replications per treatment and 25 seedlings per replication. Bacteria were applied as FS in set 1 and as FS+ RD in set 2, as described in FT 2010; plants were totally treated three times at 14-day intervals. CDM occurred naturally and severity was recorded at 8,21, and $48 \mathrm{dpt}$ according to the same rating system as described above.

Leaf and root colonization. Spontaneous rifampicin-resistant mutants of wild-type (WT) strains DP14, DS22, and HS10 - hereafter referred to as DP14rif, DS22rif, and HS10rif, respectively-were obtained using the documented method (Nautiyal 1997). The stability of rifampicin resistance in these mutants was evaluated as described earlier (Thomashow and Weller 1988). The aforementioned three WT strains and three mutants were subjected to BOX-PCR fingerprint analysis as depicted above.

DP14rif, DS22rif, and HS10rif were cultured under routine conditions in LB broth supplemented with rifampicin at $100 \mu \mathrm{g} / \mathrm{ml}$. Their cell suspensions were routinely produced as described above, then adjusted to $10^{8} \mathrm{CFU} / \mathrm{ml}$ and supplemented with Tween-20 at a final concentration of $0.01 \%$ prior to use.

In May 2011, a field trial was conducted to assess the three rifampicinresistant bacteria for colonization competence on Jinyou-35 in a plastic tent where the field soil was not pretreated with any fungicides. It involved three bacterial treatments (DP14rif, DS22rif, and HS10rif) and a nontreated control, each comprising four replications of 14 cucumber seedlings per replication. At $55 \mathrm{DAP}$, each seedling was treated with a bacterial cell suspension or sterile water (the control) as an FS+RD (60 and $25 \mathrm{ml}$ for FS and RD, respectively). Bacterial colonization competence was monitored at six time points $(0,3,7,14,21$, and $30 \mathrm{dpt})$, at each of which two cucumber plants with tightly adhering rhizosphere soil were sampled from each replication. Bacteria were isolated from leaf interior and rhizosphere soil as described by Yang et al. (2008), except that they were plated on LB agar containing rifampicin at $100 \mu \mathrm{g} / \mathrm{ml}$ and incubated at $30^{\circ} \mathrm{C}$ for $48 \mathrm{~h}$. The colonization experiment was repeated in fall 2011 following the same protocol as that described above, except using another cucumber cultivar named Wanqiu.

Plant growth assays in the greenhouse and field. Strains DP14, DS22, and HS10 were assayed for their plant-growth-promoting effect in a greenhouse experiment composed of three bacterial treatments (DP14, DS22, and HS10) and a nontreated control, each comprising three replications of 12 cucumber seedlings per replication. The leaves of each seedling at a four- or five-leaf stage were sprayed with $30 \mathrm{ml}$ of a bacterial cell suspension at $10^{8} \mathrm{CFU} / \mathrm{ml}$ (in bacterial treatments) or water (in the control). At $25 \mathrm{dpt}$, plant growth parameters (plant height, leaf area, and fresh and dry plant weights) were measured and the contents of leaf chlorophylls $a, b$, and $\mathrm{a}+\mathrm{b}$ were determined as described by Wang et al. (2013).

In 2011, DP14, DS22, and HS10 were evaluated for their effect on plant growth in a field trial consisting of four treatments (DP14, DS22, HS10, and a nontreated control), each comprising four replications of 20 cucumber plants per replication. A bacterial cell suspension at
$10^{8} \mathrm{CFU} / \mathrm{ml}$ or water (the control) was applied to plants at the 14-leaf stage only once as an FS+RD (60 and $25 \mathrm{ml}$ for FS and RD, respectively). At $30 \mathrm{dpt}$, cucumber fruit was sampled from four replications of each treatment. The water content in fruit was determined using a documented method (Silva et al. 2005) and the levels of nutrients (soluble proteins, soluble sugar, free amino acids, and vitamin C) in fruit were determined according to the protocols of Han (1996).

Data analysis. Data of cucumber disease severity, growth parameters, biomass, yield, and nutrient contents were analyzed statistically at factorial level by the analysis of variance (ANOVA), and the significant levels $(P<0.05)$ of differences among treatments were determined using a statistical software data processing system (DPS version 7.05; Zhejiang University).

When the $F$ test was significant at $P<0.05$, mean values were compared according to a least significant difference test. In two greenhouse trials (a biocontrol assay and a plant growth assay) and three field trials (two colonization assays and a plant growth assay), the only variable was bacterial treatment and the fixed factor was the method for applying bacteria. However, in FT 2010 and FT 2011, both bacterial treatment and application method were variables and included in the two-factor ANOVA. Because FT 2010 and FT 2011 were repeat experiments to determine the biocontrol efficacy of three strains (DP14, HS10, and DS22) in 2 years, the significance of time effect was examined. Data related to these experiments are presented per year in the two-factor ANOVA.

\section{Results}

Isolation of cucumber-associated bacteria. In total, 163 bacterial isolates were obtained from six cucumber microenvironments: HS, DS, HP, DP, HI, and DI. The isolates derived from DS (77), DP (24), and DI (14) consistently outnumbered their respective counterparts from HS (24), HP (20), and HI (4) (Table 2). Among all six microenvironments, DS and $\mathrm{HI}$ had the highest and lowest bacterial population densities of $5.45 \times 10^{6} \mathrm{CFU} / \mathrm{g}$ soil and $8.90 \times 10^{3} \mathrm{CFU} / \mathrm{g}$ leaf, respectively; consistently, the highest and lowest numbers of isolates were retrieved from DS (77) and HI (4), respectively (Table 2).

Production of extracellular hydrolytic enzymes and siderophores by bacteria. Of all 163 isolates, 91 (55.83\%) expressed protease, $14(8.59 \%)$ expressed chitinase, $18(11.04 \%)$ produced cellulase, and $119(73.01 \%)$ secreted siderophores (Table 2). Among all 163 isolates, only 3 (including isolate HS10; Table 1) produced all three enzymes and siderophores, 14 (8.59\%) expressed two enzymes and siderophores, 61 (37.42\%) expressed one enzyme and siderophores, 8 $(4.91 \%)$ produced only two enzymes, $9(5.52 \%)$ produced only one enzyme, 41 (25.15\%) only expressed siderophores, and 27 (16.56\%) expressed neither enzymes nor siderophores (Supplementary Table S1).

The in vitro antagonism of bacteria to $R$. solani, $P$. ultimum, and $\boldsymbol{P}$. capsici. Among the 19 isolates tested for their in vitro antagonism to $R$. solani, $P$. ultimum, and $P$. capsici, only 3 isolates (HS15, DI1, and HI2) inhibited the growth of all the three pathogens, 4 isolates (HS7,

Table 2. Number of bacteria isolated from cucumber microenvironments and their production of extracellular metabolites

\begin{tabular}{|c|c|c|c|c|c|c|}
\hline \multirow[b]{2}{*}{ Microenvironment $^{\mathbf{x}}$} & \multirow{2}{*}{$\begin{array}{l}\text { Bacterial population density } \\
\text { (CFU/g soil or leaf) }\end{array}$} & \multirow[b]{2}{*}{ Number of isolates $(\%)^{y}$} & \multicolumn{4}{|c|}{$\begin{array}{c}\text { Number of isolates producing extracellular hydrolytic } \\
\text { enzymes and siderophores }(\%)^{\mathrm{z}}\end{array}$} \\
\hline & & & Protease & Chitinase & Cellulase & Siderophores \\
\hline HS & $9.89 \times 10^{4}$ & $24(14.72)$ & $14(58.33)$ & $5(20.83)$ & $2(8.33)$ & $18(75.00)$ \\
\hline DS & $5.45 \times 10^{6}$ & $77(47.24)$ & $47(61.04)$ & $6(7.79)$ & $6(7.79)$ & $67(87.01)$ \\
\hline HP & $8.56 \times 10^{4}$ & $20(12.27)$ & $11(55.00)$ & $0(0.00)$ & $2(10.00)$ & $16(80.00)$ \\
\hline DP & $1.20 \times 10^{5}$ & $24(14.72)$ & $4(16.67)$ & $1(4.17)$ & $0(0.00)$ & $7(29.17)$ \\
\hline HI & $8.90 \times 10^{3}$ & $4(2.45)$ & $3(75.00)$ & $2(50.00)$ & $3(75.00)$ & $4(100.00)$ \\
\hline DI & $2.48 \times 10^{4}$ & $14(8.59)$ & $12(85.71)$ & $0(0.00)$ & $5(35.71)$ & $7(50.00)$ \\
\hline Total & $\ldots$ & $163(100.00)$ & $91(55.83)$ & $14(8.59)$ & $18(11.04)$ & $119(73.01)$ \\
\hline
\end{tabular}

${ }^{\mathrm{x}} \mathrm{HS}$ and DS = mixed rhizosphere and surrounding bulk soils of healthy and diseased plants, respectively; HP and DP = the phyllosphere of healthy and diseased plants, respectively; and $\mathrm{HI}$ and DI = the leaf interior of healthy and diseased plants, respectively.

${ }^{\mathrm{y}}$ Percentage of isolates from a specific microenvironment $=($ number of isolates from this microenvironment $/ 163) \times 100 \%$.

${ }^{\mathrm{z}}$ Percentage of isolates producing a specific enzyme or siderophores from a specific microenvironment $=$ (number of isolates with this ability from this microenvironment/total number of isolates from this microenvironment) $\times 100 \%$. 
DS59, HI1, and DS58) only showed the antagonistic activity against $R$. solani, DP14 was only antagonistic toward P. ultimum, and HS10 and DS79 only inhibited the growth of $P$. capsici (Table 1).

BOX-PCR fingerprint analysis of bacterial isolates. BOX-PCR fingerprint analysis identified 30 distinct groups (G1 to G30) with the similarity coefficient of $50 \%$ among the 163 isolates; isolates in

Table 3. Closest affiliations of five antagonistic bacterial strains

\begin{tabular}{llc}
\hline Strain & \multicolumn{1}{c}{$\begin{array}{c}\text { Closest strain in GenBank library } \\
\text { (accession number) }\end{array}$} & Similarity (\%) \\
\hline DS22 & Bacillus pumilus (KU314512) & 99 \\
HS10 & B. licheniformis (KU314515) & 99 \\
DP14 & Enterobacter sp. (KU314514) & 99 \\
DS57 & Stenotrophomonas maltophilia (KU314513) & 99 \\
HP4 & Bacillus sp. (KU314516) & 99 \\
\hline
\end{tabular}

different groups had dissimilar genotypes (Supplementary Fig. S1). Based on the standard that the isolates with $\geq 90 \%$ sequence similarities are considered the same species, the 163 isolates were found to belong to 125 distinct species. Among the isolates with $\geq 90 \%$ sequence similarities, a few were from different microenvironments, consisting of DI3 and DS24 from two microenvironments (DI and DS) and DI5, DI11, DS27, and HP8 from three microenvironments (DI, DS, and HP), while a vast majority of such isolates were from the same microenvironments, such as DI4 and DI6 from DI, and HP1, HP14, and HP12 from HP. Taking into account the genetic information on the 163 isolates, 19 genetically distinct isolates were selected for the biocontrol assay in the greenhouse, as indicated below (Table 1).

The control of CDM by 19 representative isolates in the greenhouse. Applied as an FS, the 19 selected isolates showed biocontrol efficacy ranging from 30.28 to $87.81 \%$ at 15 dpi (Table 1), of which DS22 and DP14 achieved the highest levels of efficacy (87.81

Table 4. Suppression of cucurbit downy mildew (CDM) by five bacterial strains in field trial (FT) $2010^{y}$

\begin{tabular}{|c|c|c|c|c|c|c|c|c|c|}
\hline \multirow[b]{2}{*}{$\begin{array}{l}\text { Method of application, } \\
\text { treatment }^{\mathrm{z}}\end{array}$} & \multicolumn{3}{|c|}{$8 \mathrm{dpt}$} & \multicolumn{3}{|c|}{$15 \mathrm{dpt}$} & \multicolumn{3}{|c|}{$22 \mathrm{dpt}$} \\
\hline & $\begin{array}{c}\text { Disease severity } \\
(\%)\end{array}$ & $\begin{array}{c}\text { Efficacy } \\
(\%)\end{array}$ & $\begin{array}{l}\text { RE } \\
(\%)\end{array}$ & $\begin{array}{c}\text { Disease severity } \\
(\%)\end{array}$ & $\begin{array}{c}\text { Efficacy } \\
(\%)\end{array}$ & $\begin{array}{l}\mathbf{R E} \\
(\%)\end{array}$ & $\begin{array}{c}\text { Disease severity } \\
(\%)\end{array}$ & $\begin{array}{c}\text { Efficacy } \\
(\%)\end{array}$ & $\begin{array}{l}\text { RE } \\
(\%)\end{array}$ \\
\hline \multicolumn{10}{|l|}{ FS } \\
\hline DS22 & $4.43 \pm 1.85 \mathrm{c}$ & 73.07 & 89.20 & $4.64 \pm 1.84 \mathrm{~cd}$ & 76.96 & 83.85 & $8.74 \pm 2.77 b$ & 66.19 & 82.16 \\
\hline DP14 & $6.71 \pm 1.74 \mathrm{bc}$ & 59.22 & 72.29 & $5.63 \pm 0.69 \mathrm{~cd}$ & 72.06 & 78.51 & $9.11 \pm 2.13 b$ & 64.75 & 80.37 \\
\hline HP4 & $12.37 \pm 4.27 \mathrm{ab}$ & 24.80 & 30.28 & $11.61 \pm 2.30 \mathrm{bc}$ & 42.39 & 46.19 & $15.62 \pm 4.69 \mathrm{ab}$ & 39.54 & 49.08 \\
\hline HS10 & $6.68 \pm 0.93 b c$ & 59.39 & 72.50 & $5.52 \pm 1.53 \mathrm{~cd}$ & 72.63 & 79.13 & $9.74 \pm 2.81 \mathrm{~b}$ & 62.31 & 77.35 \\
\hline DS57 & $9.85 \pm 3.80 \mathrm{ab}$ & 40.14 & 49.00 & $13.28 \pm 3.28 \mathrm{ab}$ & 34.11 & 37.16 & $18.02 \pm 9.22 \mathrm{a}$ & 30.26 & 37.56 \\
\hline Fungicide & $2.97 \pm 0.73 \mathrm{c}$ & 81.92 & 100.00 & $1.66 \pm 0.83 \mathrm{~d}$ & 91.78 & 100.00 & $5.02 \pm 0.25 \mathrm{~b}$ & 80.56 & 100.00 \\
\hline Control & $16.45 \pm 1.80 \mathrm{a}$ & $\ldots$ & $\ldots$ & $20.15 \pm 4.24 \mathrm{a}$ & $\ldots$ & $\ldots$ & $25.84 \pm 7.18 \mathrm{a}$ & $\ldots$ & $\ldots$ \\
\hline$P$ value & 0.0238 & $\ldots$ & $\ldots$ & 0.0027 & $\ldots$ & $\ldots$ & 0.0175 & $\ldots$ & $\ldots$ \\
\hline \multicolumn{10}{|l|}{$\mathrm{FS}+\mathrm{RD}$} \\
\hline DS22 & $2.53 \pm 0.00 \mathrm{ab}$ & 57.83 & 108.74 & $2.16 \pm 1.47 \mathrm{~b}$ & 74.40 & 123.20 & $6.45 \pm 1.90 \mathrm{bc}$ & 54.57 & 73.99 \\
\hline DP14 & $1.54 \pm 0.00 \mathrm{~b}$ & 74.31 & 139.73 & $1.62 \pm 0.91 b$ & 80.81 & 133.81 & $6.42 \pm 2.69 b c$ & 54.85 & 74.37 \\
\hline HP4 & $2.85 \pm 1.65 \mathrm{ab}$ & 52.45 & 98.63 & $2.43 \pm 1.34 \mathrm{~b}$ & 71.27 & 118.02 & $5.37 \pm 1.81 b c$ & 62.23 & 84.38 \\
\hline HS10 & $2.38 \pm 2.23 \mathrm{ab}$ & 60.25 & 113.29 & $0.88 \pm 0.77 b$ & 89.57 & 148.32 & $3.20 \pm 2.16 \mathrm{c}$ & 77.49 & 105.07 \\
\hline DS57 & $3.46 \pm 1.82 \mathrm{ab}$ & 42.28 & 79.50 & $5.94 \pm 3.64 \mathrm{ab}$ & 29.62 & 49.05 & $8.53 \pm 1.55 b c$ & 39.97 & 54.20 \\
\hline Fungicide & $2.81 \pm 0.78 \mathrm{ab}$ & 53.18 & 100.00 & $3.35 \pm 2.45 \mathrm{ab}$ & 60.39 & 100.00 & $3.73 \pm 1.31 \mathrm{c}$ & 73.75 & 100.00 \\
\hline Control & $6.00 \pm 4.11 \mathrm{a}$ & $\ldots$ & $\ldots$ & $8.45 \pm 3.91 \mathrm{ab}$ & $\ldots$ & $\ldots$ & $14.21 \pm 7.14 \mathrm{ab}$ & $\ldots$ & $\ldots$ \\
\hline$P$ value & 0.6327 & $\ldots$ & $\ldots$ & 0.1086 & $\ldots$ & $\ldots$ & 0.3328 & $\ldots$ & $\ldots$ \\
\hline \multicolumn{10}{|l|}{$\mathrm{RD}$} \\
\hline DS22 & $23.94 \pm 7.69 \mathrm{ab}$ & 27.84 & 91.40 & $23.02 \pm 10.33 \mathrm{ab}$ & 38.26 & 158.50 & $34.82 \pm 10.97 \mathrm{ab}$ & 28.57 & 97.58 \\
\hline DP14 & $16.62 \pm 4.17 \mathrm{~b}$ & 49.91 & 163.85 & $13.71 \pm 3.85 b$ & 63.23 & 261.92 & $31.37 \pm 9.06 \mathrm{~b}$ & 35.65 & 121.76 \\
\hline HP4 & $18.66 \pm 3.71 \mathrm{~b}$ & 43.75 & 143.63 & $18.58 \pm 5.71 \mathrm{ab}$ & 50.19 & 207.92 & $34.13 \pm 9.56 \mathrm{ab}$ & 29.99 & 102.42 \\
\hline HS10 & $15.95 \pm 3.36 b$ & 51.91 & 170.42 & $15.19 \pm 7.42 b$ & 59.25 & 245.46 & $39.50 \pm 7.13 \mathrm{ab}$ & 18.96 & 64.75 \\
\hline DS57 & $26.79 \pm 3.06 \mathrm{ab}$ & 19.27 & 63.27 & $30.68 \pm 11.46 \mathrm{ab}$ & 17.74 & 73.48 & $49.21 \pm 12.26 \mathrm{a}$ & -0.95 & -3.24 \\
\hline Fungicide & $23.07 \pm 1.76 \mathrm{ab}$ & 30.46 & 100.00 & $28.29 \pm 1.81 \mathrm{ab}$ & 24.14 & 100.00 & $34.48 \pm 5.62 \mathrm{ab}$ & 29.28 & 100.00 \\
\hline Control & $33.18 \pm 5.65 \mathrm{a}$ & $\ldots$ & $\ldots$ & $37.29 \pm 4.01 \mathrm{a}$ & $\ldots$ & $\ldots$ & $48.75 \pm 4.52 \mathrm{a}$ & $\ldots$ & $\ldots$ \\
\hline$P$ value & 0.0697 & $\ldots$ & $\ldots$ & 0.1251 & $\ldots$ & $\ldots$ & 0.2603 & $\ldots$ & $\ldots$ \\
\hline
\end{tabular}

y Abbreviations: $\mathrm{dpt}=$ days post first bacterial treatment and $\mathrm{RE}=$ relative efficacy, which stands for the control efficacy of a strain relative to that of propamocarb.

${ }^{\mathrm{z}}$ Bacteria were applied to plants as foliar spray (FS) in set 1, FS plus root drench (FS+RD) in set 2, and root drench (RD) in set 3; the three sets of treatments constituted the single field experiment FT 2010. Data are presented as means of four replicates \pm standard errors; different letters indicate significant differences between treatments according to a least significant difference test at $P<0.05$.

Table 5. Results of bacterial treatments across application methods in field trial (FT) 2010 and FT 2011

\begin{tabular}{|c|c|c|c|c|c|c|}
\hline \multirow[b]{2}{*}{ Factor $^{\mathbf{Z}}$} & \multicolumn{3}{|c|}{2010} & \multicolumn{3}{|c|}{2011} \\
\hline & Disease severity (\%) & Efficacy (\%) & ARE (\%) & Disease severity (\%) & Efficacy (\%) & ARE (\%) \\
\hline FS & $10.19 \pm 6.23 b$ & $59.56 \pm 19.79 \mathrm{a}$ & $64.31 \pm 20.19 \mathrm{c}$ & $16.44 \pm 7.61 \mathrm{a}$ & $53.24 \pm 10.69 \mathrm{a}$ & $78.23 \pm 16.77 \mathrm{~b}$ \\
\hline $\mathrm{FS}+\mathrm{RD}$ & $4.49 \pm 3.14 \mathrm{c}$ & $61.62 \pm 15.53 \mathrm{a}$ & $100.29 \pm 30.34 b$ & $17.16 \pm 6.91 \mathrm{a}$ & $50.36 \pm 10.62 \mathrm{a}$ & $108.89 \pm 17.11 \mathrm{a}$ \\
\hline $\mathrm{RD}$ & $28.44 \pm 10.37 \mathrm{a}$ & $34.30 \pm 16.43 b$ & $130.87 \pm 72.51 \mathrm{a}$ & $\ldots$ & $\ldots$ & $\ldots$ \\
\hline \multicolumn{7}{|l|}{$P$ value } \\
\hline Application method (A) & 0.0001 & 0.0001 & 0.0001 & 0.5420 & 0.4609 & 0.0035 \\
\hline Bacterial treatment (B) & 0.0001 & 0.0001 & 0.0001 & 0.0001 & 0.1161 & 0.1142 \\
\hline $\mathrm{A} \times \mathrm{B}$ & 0.0368 & 0.0002 & 0.1019 & 0.4645 & 0.2357 & 0.9593 \\
\hline
\end{tabular}

y ARE $=$ average relative efficacy. Data are presented as means of four replicates \pm standard errors. Different letters indicate significant differences between treatments according to a least significant difference test at $P<0.05$.

${ }^{\mathrm{z}}$ Bacteria were applied to plants as foliar spray (FS), FS plus root drench (FS+RD), or root drench (RD) in FT 2010 and as FS or FS+RD in FT 2011. 
and 70.66\%, respectively) and four other isolates (HP4, HS10, HS15, and DS57) also attained relatively high efficacy $(>60 \%)$.

Identification of five isolates and their field efficacy against CDM. By comparing their 16S rDNA sequences with those in the Nucleotide Sequence Database of NCBI, isolates DP14, DS22, HS10, HP4, and DS57 were identified as Enterobacter sp., B. pumilus, B. licheniformis, Bacillus sp., and Stenotrophomonas maltophilia, respectively (Table 3). They were assessed for their efficacy against naturally occurring CDM in FT 2010, which was a single experiment consisting of three sets differing in application method. Compared with the nontreated control, DP14 and HS10 significantly reduced disease severity with each of the three application methods (FS, FS+RD, and RD) at at least one time point (Table 4); DS22 significantly suppressed the disease with FS, HP4 provided significant disease protection with FS and RD, whereas DS57 failed to significantly reduce disease severity with any application method (Table 4).
Overall, bacterial treatments attained significantly higher efficacy with FS and FS+RD than with RD, whereas no significant differences in efficacy occurred between bacterial treatments as FS and as FS+RD (Table 5). On the other hand, we noticed that the control efficacy for propamocarb itself varied in different sets (Table 4). Thus, to more accurately determine the impact of a specific application method on the biocontrol activity of each strain, we calculated its efficacy relative to that of propamocarb, hereafter referred to as relative efficacy, at each time point in each set, as well as its average relative efficacy (ARE) over the time course in FT 2010 (Table 4). The overall ARE of bacterial treatments was significantly higher with FS+RD (100.29\%) than with FS $(64.31 \%)$ (Table 5).

The consistency in the field performance of strains DP14, DS22, and HS10 was evaluated in FT 2011, for which the time course was 48 days, twofold longer than that of FT 2010 (21 days). FT 2011 was a single experiment comprising sets 1 and 2 using FS

Table 6. Suppression of cucurbit downy mildew by three antagonistic bacteria in field trial (FT) $2011^{y}$

\begin{tabular}{|c|c|c|c|c|c|c|c|c|c|}
\hline \multirow[b]{2}{*}{$\begin{array}{l}\text { Method of application, } \\
\text { treatment }^{z}\end{array}$} & \multicolumn{3}{|c|}{$8 \mathrm{dpt}$} & \multicolumn{3}{|c|}{$21 \mathrm{dpt}$} & \multicolumn{3}{|c|}{$48 \mathrm{dpt}$} \\
\hline & $\begin{array}{c}\text { Disease severity } \\
(\%)\end{array}$ & $\begin{array}{c}\text { Efficacy } \\
(\%)\end{array}$ & $\begin{array}{l}\mathrm{RE} \\
(\%)\end{array}$ & $\begin{array}{c}\text { Disease severity } \\
(\%)\end{array}$ & $\begin{array}{c}\text { Efficacy } \\
(\%)\end{array}$ & $\begin{array}{l}\text { RE } \\
(\%)\end{array}$ & $\begin{array}{c}\text { Disease severity } \\
(\%)\end{array}$ & $\begin{array}{c}\text { Efficacy } \\
(\%)\end{array}$ & $\begin{array}{l}\mathrm{RE} \\
(\%)\end{array}$ \\
\hline \multicolumn{10}{|l|}{ FS } \\
\hline DS22 & $10.28 \pm 2.34 b$ & 58.46 & 88.02 & $9.93 \pm 3.27 \mathrm{bc}$ & 62.14 & 101.94 & $16.16 \pm 1.11 \mathrm{~b}$ & 53.09 & 83.06 \\
\hline DP14 & $13.59 \pm 1.13 b$ & 45.09 & 67.88 & $12.62 \pm 1.06 \mathrm{~b}$ & 51.89 & 85.12 & $16.58 \pm 1.06 \mathrm{~b}$ & 51.87 & 81.15 \\
\hline HS10 & $13.39 \pm 3.94 b$ & 45.90 & 69.10 & $12.60 \pm 0.77 b$ & 51.96 & 85.24 & $25.08 \pm 3.03 \mathrm{ab}$ & 27.20 & 42.55 \\
\hline Fungicide & $8.31 \pm 5.10 b$ & 66.42 & 100.00 & $10.24 \pm 1.32 b c$ & 60.96 & 100.00 & $12.43 \pm 1.47 \mathrm{~b}$ & 63.92 & 100.00 \\
\hline Control & $24.75 \pm 5.92 \mathrm{a}$ & $\ldots$ & $\ldots$ & $26.23 \pm 6.78 \mathrm{a}$ & $\ldots$ & $\ldots$ & $34.45 \pm 14.26 \mathrm{a}$ & $\ldots$ & $\ldots$ \\
\hline$P$ value & 0.0922 & $\ldots$ & $\ldots$ & 0.0991 & $\ldots$ & $\ldots$ & 0.2034 & $\ldots$ & $\ldots$ \\
\hline \multicolumn{10}{|l|}{$\mathrm{FS}+\mathrm{RD}$} \\
\hline DS22 & $12.08 \pm 3.09 \mathrm{~b}$ & 47.93 & 125.93 & $14.88 \pm 2.15 b$ & 49.81 & 97.17 & $10.87 \pm 5.57 \mathrm{~b}$ & 68.93 & 132.02 \\
\hline DP14 & $14.54 \pm 5.54 b$ & 37.33 & 98.07 & $14.75 \pm 5.10 b$ & 50.25 & 98.03 & $10.24 \pm 3.85 b$ & 70.73 & 135.47 \\
\hline HS 10 & $14.20 \pm 3.62 b$ & 38.79 & 101.93 & $15.78 \pm 2.51 \mathrm{~b}$ & 46.78 & 91.25 & $16.70 \pm 1.04 \mathrm{~b}$ & 52.27 & 100.11 \\
\hline Fungicide & $14.37 \pm 2.54 b$ & 38.06 & 100.00 & $14.45 \pm 3.81 b$ & 51.26 & 100.00 & $16.72 \pm 2.35 b$ & 52.21 & 100.00 \\
\hline Control & $23.20 \pm 3.36 \mathrm{a}$ & $\ldots$ & $\ldots$ & $29.65 \pm 8.06 \mathrm{a}$ & $\ldots$ & $\ldots$ & $34.99 \pm 5.41 \mathrm{a}$ & $\ldots$ & $\ldots$ \\
\hline$P$ value & 0.2714 & $\ldots$ & $\ldots$ & 0.2186 & $\ldots$ & $\ldots$ & 0.0224 & $\ldots$ & $\ldots$ \\
\hline
\end{tabular}

${ }^{y}$ Abbreviations: $\mathrm{dpt}=$ days post first bacterial treatment and $\mathrm{RE}=$ relative efficacy

${ }^{\mathrm{z}}$ Bacteria were applied to plants as foliar spray (FS) and FS plus root drench (FS+RD) in sets 1, and 2, respectively; the two sets constituted the single field experiment FT 2011. Data are presented as means of four replicates \pm standard errors. Different letters indicate significant differences between treatments according to a least significant difference test at $P<0.05$.

Table 7. Results of bacterial treatments as foliar spray (FS) or FS plus root drench (FS+RD) across field trial (FT) years 2010 and $2011^{\mathrm{y}}$

\begin{tabular}{|c|c|c|c|c|c|c|}
\hline \multirow[b]{2}{*}{ Factor $^{\mathbf{z}}$} & \multicolumn{3}{|c|}{ FS } & \multicolumn{3}{|c|}{$\mathbf{F S}+\mathbf{R D}$} \\
\hline & Disease severity (\%) & Efficacy (\%) & ARE (\%) & Disease severity (\%) & Efficacy (\%) & ARE (\%) \\
\hline 2010 & $8.89 \pm 6.78 b$ & $71.74 \pm 9.96 \mathrm{a}$ & $79.48 \pm 5.33 \mathrm{a}$ & $4.38 \pm 3.48 b$ & $67.62 \pm 12.16 \mathrm{a}$ & $113.39 \pm 26.44 a$ \\
\hline 2011 & $16.44 \pm 7.61 \mathrm{a}$ & $53.24 \pm 10.69 \mathrm{~b}$ & $78.23 \pm 16.77 \mathrm{a}$ & $17.16 \pm 6.91 \mathrm{a}$ & $50.36 \pm 10.62 \mathrm{~b}$ & $108.89 \pm 17.11 a$ \\
\hline \multicolumn{7}{|l|}{$P$ value for } \\
\hline Year (A) & 0.0001 & 0.0001 & 0.7896 & 0.0001 & 0.0012 & 0.7073 \\
\hline Bacterial treatment (B) & 0.0001 & 0.0001 & 0.0922 & 0.0001 & 0.5740 & 0.7456 \\
\hline$A \times B$ & 0.3706 & 0.0744 & 0.1077 & 0.0158 & 0.3985 & 0.4945 \\
\hline
\end{tabular}

Table 8. Average relative efficacy (ARE) of strains DP14, DS22, and HS10 applied as foliar spray (FS) or FS plus root drench (FS+RD) in field trial (FT) 2010 and FT 2011

\begin{tabular}{|c|c|c|c|c|c|c|c|c|c|}
\hline \multirow[b]{2}{*}{ Treatment } & \multicolumn{3}{|c|}{$\operatorname{ARE} \operatorname{FS}(\%)^{x}$} & \multicolumn{3}{|c|}{ ARE FS+RD $(\%)^{y}$} & \multicolumn{3}{|c|}{ ARE increase $(\%)^{z}$} \\
\hline & 2010 & 2011 & 2-year & 2010 & 2011 & 2-year & 2010 & 2011 & 2-year \\
\hline DP14 & 77.06 & 91.00 & 84.03 & 115.97 & 118.38 & 117.17 & 50.50 & 30.08 & 40.29 \\
\hline DS22 & 85.07 & 78.05 & 81.56 & 101.98 & 110.52 & 106.25 & 19.88 & 41.60 & 30.74 \\
\hline HS10 & 76.33 & 65.63 & 70.98 & 122.23 & 97.76 & 109.99 & 60.14 & 48.96 & 54.55 \\
\hline Propamocarb & 100.00 & 100.00 & 100.00 & 100.00 & 100.00 & $\ldots$ & 0.00 & 0.00 & 0.00 \\
\hline
\end{tabular}

${ }^{x}$ ARE due to FS.

y ARE due to FS+RD.

${ }^{\mathrm{z}} \mathrm{ARE}$ increase $(\%)=\left[\left(\mathrm{ARE}^{\mathrm{FS}+\mathrm{RD}}-\mathrm{ARE}^{\mathrm{FS}}\right) /\left(\mathrm{ARE}^{\mathrm{FS}}\right)\right] \times 100 \%$. 
and FS+RD, respectively. All three strains significantly suppressed naturally occurring CDM throughout the time course with FS+RD; however, applied as FS, only strains DS22 and DP14 significantly reduced disease symptoms throughout the time course, while HS10 achieved significant efficacy at 8 and $21 \mathrm{dpt}$ but not at $48 \mathrm{dpt}$ (Table 6). This indicated that these strains attained more durable efficacy with FS+RD than with FS; consistently, each strain showed a higher level of efficacy with FS+RD than with FS at $48 \mathrm{dpt}(68.93$ versus $53.09 \%$ for DP14, 70.73 versus $51.87 \%$ for DS22, and 52.27 versus $27.20 \%$ for HS10). On the other hand, the two application methods did not cause significant differences in the overall efficacy of the three strains (Table 5); however, their overall ARE was significantly
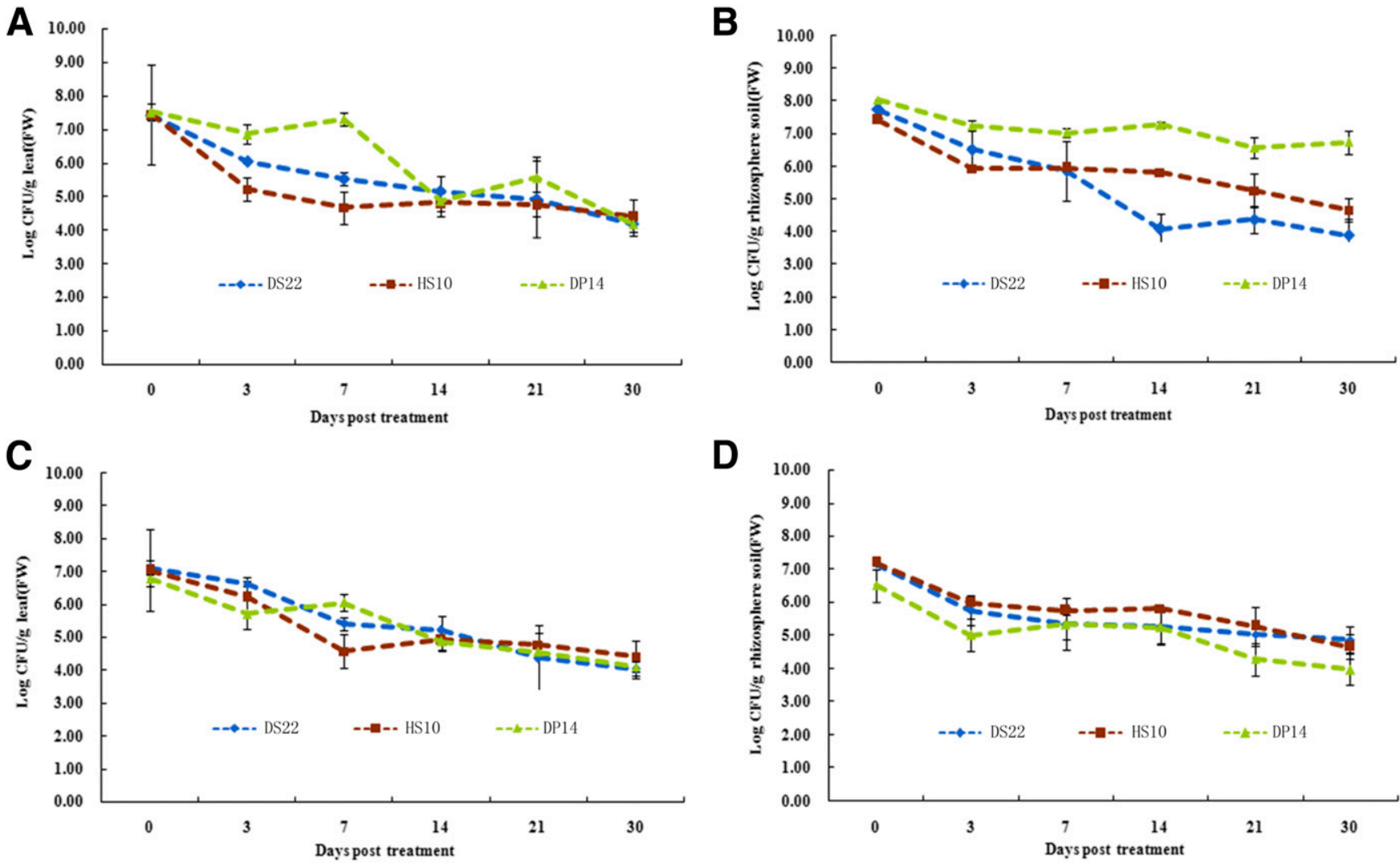

Fig. 1. Competence of DP14, DS22, and HS10 to colonize leaves and rhizosphere of two cucumber cultivars (Jinyou-35 and Wanqiu) under field conditions. A, Population densities of DP14rif, DS22rif, and HS10rif in Jinyou-35 leaves over the time course. B, Population densities of these strains in Jinyou-35 rhizosphere over the time course. C, Population densities of these strains in Wanqiu leaves over the time course. D, Population densities of these strains in Wanqiu rhizosphere over the time course. Data are presented as means of four replicates \pm standard errors.

Table 9. Plant-growth-promoting effect of DP14, DS22, and HS10 under greenhouse conditions ${ }^{\mathrm{z}}$

\begin{tabular}{lcccccc}
\hline Treatment & Height $(\mathbf{c m})$ & Leaf area $\left(\mathbf{c m}^{\mathbf{2}}\right)$ & Fresh weight $(\mathbf{g})$ & Fresh weight increase $(\boldsymbol{\%})$ & Dry weight $(\mathbf{g})$ & Dry weight increase $(\boldsymbol{\%})$ \\
\hline DP14 & $33.38 \pm 1.59 \mathrm{ab}$ & $105.38 \pm 9.35 \mathrm{abc}$ & $14.15 \pm 0.39 \mathrm{abc}$ & 28.52 & $5.50 \pm 0.04 \mathrm{a}$ & 30.33 \\
DS22 & $28.62 \pm 1.29 \mathrm{c}$ & $101.27 \pm 5.06 \mathrm{bcd}$ & $11.51 \pm 0.67 \mathrm{~cd}$ & 4.54 & $5.27 \pm 0.05 \mathrm{a}$ & 24.88 \\
HS10 & $33.22 \pm 4.24 \mathrm{ab}$ & $93.57 \pm 0.82 \mathrm{de}$ & $12.73 \pm 2.47 \mathrm{~b} \mathrm{~cd}$ & 15.62 & $4.89 \pm 0.43 \mathrm{ab}$ & 15.88 \\
Control & $26.77 \pm 4.53 \mathrm{~d}$ & $92.34 \pm 18.98 \mathrm{de}$ & $11.01 \pm 1.57 \mathrm{~d}$ & - & $4.22 \pm 0.52 \mathrm{c}$ & - \\
$P$ value & 0.7626 & 0.6729 & 0.7601 & & 0.6507 & \\
\hline
\end{tabular}

${ }^{\mathrm{z}}$ Height, leaf area, fresh weight, and dry weight of cucumber plants were measured at 25 days post first bacterial treatment. Data are presented as means of four replicates \pm standard errors. Different letters indicate significant differences between treatments according to a least significant difference test at $P<0.05$.

Table 10. Effect of DP14, DS22, and HS10 on the size and yield of cucumber fruit under field conditions ${ }^{\mathrm{y}}$

\begin{tabular}{|c|c|c|c|c|c|c|c|}
\hline Treatment & Transverse diameter $(\mathbf{T})$ & Longitudinal diameter $(\mathrm{L})$ & $\mathbf{L} / \mathbf{T}$ & Single fruit weight (g) & Fruit number ${ }^{\mathrm{z}}$ & Yield $(g)^{\mathbf{z}}$ & $\begin{array}{c}\text { Single plant } \\
\text { increment }(\%)\end{array}$ \\
\hline$\overline{\mathrm{DP} 14}$ & $3.39 \pm 0.15 b c$ & $32.00 \pm 1.00 \mathrm{a}$ & $9.53 \pm 0.38 \mathrm{ab}$ & $239.61 \pm 6.38 \mathrm{ab}$ & 21 & $5,031.81$ & 51.03 \\
\hline DS22 & $3.19 \pm 0.17 b c$ & $31.23 \pm 0.57 \mathrm{a}$ & $9.84 \pm 0.39 \mathrm{a}$ & $229.21 \pm 7.70 \mathrm{abc}$ & 20 & $4,584.20$ & 37.60 \\
\hline HS 10 & $3.69 \pm 0.19 a b$ & $30.81 \pm 0.41 \mathrm{a}$ & $8.42 \pm 0.38 b c$ & $230.25 \pm 34.43 a b c$ & 20 & $4,605.00$ & 38.22 \\
\hline control & $3.02 \pm 0.31 \mathrm{c}$ & $27.80 \pm 2.96 \mathrm{~b}$ & $7.66 \pm 0.15 b c$ & $185.09 \pm 63.30 \mathrm{c}$ & 18 & $3,331.62$ & $\ldots$ \\
\hline$P$ value & 0.5156 & 0.3841 & 0.0052 & 0.5267 & $\ldots$ & $\ldots$ & $\ldots$ \\
\hline
\end{tabular}

${ }^{y}$ Cucumber fruit was sampled to measure their size and weight at 30 days post first bacterial treatment. Data are presented as means of four replicates \pm standard errors; different letters indicate significant differences between treatments according to a least significant difference test at $P<0.05$.

${ }^{\mathrm{z}}$ Fruit number or yield of a single plant. 
greater with FS+RD (108.89\%) than with FS (78.23\%) (Table 5). Furthermore, no significant time effect on ARE was detected between FT 2010 and FT 2011 (Table 7); thus, the ARE values of the two trials were pooled, resulting in 2-year ARE. As a result, the 2-year ARE for DS22, DP14, and HS10 was substantially greater with FS+RD (106.25 to $117.17 \%$ ) than with FS (70.98 to $84.03 \%)$; the increases in this parameter due to FS+RD were 54.55, 40.29, and $30.74 \%$ for HS10, DP14, and DS22, respectively, relative to FS (Table 8).

The colonization competence of DP14, DS22, and HS10. Spontaneous rifampicin-resistant mutants DP14rif, DS22rif, and HS10rif were shown to be the same as their respective WT strains in colonial characteristics (color, shape, size, elevation, and margin type) and the banding patterns generated in the BOX-PCR fingerprint analysis (data not shown), signifying that the mutants shared common phenotypes and genotypes with the WT strains.

In the colonization experiment with Jinyou-35, DP14rif, DS22rif, and HS10rif colonized leaves with population densities ranging from $10^{4}$ to $10^{7} \mathrm{CFU} / \mathrm{g}$ leaf over the time course $(0,3,7,14,21$, and 30 dpt) (Fig. 1A). Although DP14rif exceeded the other two at the middle time points, especially $7 \mathrm{dpt}$, HS10rif, DP14rif, and DS22rif had similar leaf population sizes $\left[(2.63 \pm 0.49) \times 10^{4},(1.55 \pm 0.35) \times 10^{4}\right.$, and $(1.51$ $\pm 0.22) \times 10^{4} \mathrm{CFU} / \mathrm{g}$ of leaf, respectively] at $30 \mathrm{dpt}$. Concerning their rhizosphere competence, DP14rif outperformed the other two over the time course (Fig. 1B); at $30 \mathrm{dpt}$, the rhizosphere population sizes of DP14rif, HS10rif, and DS22rif varied, standing at $(5.49 \pm 0.35) \times$ $10^{6},(4.68 \pm 0.35) \times 10^{4}$, and $(7.94 \pm 0.51) \times 10^{3} \mathrm{CFU} / \mathrm{g}$ of rhizosphere soil, respectively. The colonization experiment was repeated under field conditions on another cucumber cultivar, Wanqiu; as a result, the leaf and rhizosphere population dynamics of the three mutants in this cultivar (Fig. 1C and D) were generally similar to their counterparts in Jinyou-35. Because the three mutants had the same phenotypes and genotypes as their respective WT strains, they could reflect their WT strains in leaf and rhizosphere colonization patterns.

The plant-growth-promoting effect of DP14, DS22, and HS10 under greenhouse and field conditions. In the greenhouse experiment, strains DP14, DS22, and HS10 applied as an FS significantly augmented plant height and dry weight at $25 \mathrm{dpt}$ relative to the nontreated control, thereby increasing biomass (based on dry weight) by $30.33,24.88$, and $15.88 \%$, respectively; and DP14 also resulted in greater leaf area and plant fresh weight (Table 9). On the other hand, bacterial treatments did not elevate contents of leaf chlorophylls a, b, and $a+b$ to a statistically significant extent relative to the nontreated control. The means of leaf chlorophyll contents in replications of treatments DP14, DS22, and HS10, and the control stood at 352.39 \pm $23.05,375.13 \pm 48.80,368.92 \pm 18.70$, and $371.42 \pm 41.68 \mathrm{mg} / \mathrm{g}$, respectively, for chlorophyll a; $110.43 \pm 36.46,114.51 \pm 52.51$, $66.64 \pm 13.74$, and $28.81 \pm 26.90 \mathrm{mg} / \mathrm{g}$, respectively, for chlorophyll b; and 462.82 $\pm 58.86,489.64 \pm 95.38,435.5 \pm 39.72$, and $400.23 \pm$ $43.75 \mathrm{mg} / \mathrm{g}$, respectively, for chlorophyll a+b.

In the field experiment aimed to examine their growth-promoting effect, treatments DP14, DS22, and HS10 as an FS+RD significantly increased the longitudinal diameter of cucumber fruit relative to the nontreated control at $30 \mathrm{dpt}$; DP14 and HS10 also significantly increased single-fruit weight and the transverse diameter of fruit, respectively (Table 10). Moreover, DP14, HS10, and DS22 improved single-plant yield by $51.03,38.22$, and $37.60 \%$, respectively. In addition, water content in fruit rose extensively with all bacterial treatments compared with the nontreated control (Fig. 2A), as did nutrient levels in fruit-higher contents of soluble sugar and free amino acid noted with DP14 (Fig. 2C and D), greater levels of soluble protein and Vc observed with DS22 (Fig. 2B and E), and higher contents of soluble sugar, Vc, and free amino acid recorded with HS10 (Fig. 2C to E).

In contrast, both bacterial treatments and the nontreated control showed no symptoms of CDM at $15 \mathrm{dpt}$ in this field experiment; at the same time, leaf spots, which were not caused by $P$. cubensis, occurred sporadically in all treatments.

\section{Discussion}

Intending to find promising BCAs against CDM, we isolated bacteria from both healthy and diseased cucumber plants. Among the four strains showing significant biocontrol activity in FT 2010, two (HS10 and HP4) were derived from healthy plants and another two (DS22 and DP14) from diseased ones, suggesting that both healthy and diseased plants are a reservoir of potential BCAs. Concerning their microenvironment-specific distribution, half (DS22 and HS10) originated from the mixed rhizosphere and surrounding bulk soils and the other half (DP14 and HP4) from the phyllosphere. Hence, among the sampled microenvironments, bacterial antagonists to $P$. cubensis are more abundant in soils and phyllosphere than in leaf interior (HI and DI), which aligned with the fact that the former outnumbered the latter substantially in bacterial population size (Table 2).

Nineteen isolates were selected for the greenhouse biocontrol assay based on their diversity of source (microenvironment) and genotype revealed in BOX-PCR fingerprint analysis, in vitro antagonism, the ability to produce extracellular hydrolytic enzymes or siderophores, and assumed potential for inducing plant systemic resistance. The ability to produce extracellular hydrolytic enzymes and siderophores is an important biocontrol mechanism of antagonistic bacteria (Fravel 1988; Kloepper et al. 1980; Lorito et al. 1993; Priyanka et al. 2017). Among the three strains with consistent performance in field trials, HS10 produced all three tested enzymes and siderophores; DS22 produced protease, cellulase, and siderophores; but DP14 only weakly produced chitinase (Table 1 ). Based on the remarkable difference between HS10 and DP14, we had predicted that HS10 might be effective against CDM and that DP14 might have the capacity to elicit systemic resistance if it could significantly reduce CDM. In the two field trials, as predicted, HS10 attained significant biocontrol efficacy with FS and FS+RD but, unexpectedly, it also significantly reduced the disease with RD. Regarding DP14, its significant suppression of the disease with RD supports our hypothesis that it might have the ability to elicit systemic resistance such as ISR. However, we were surprised that DP14 was also as effective as HS10 in reducing $\mathrm{CDM}$ when applied as FS given their striking differences in the ability to produce the enzymes and siderophores. This may be attributed to the fact that DP14 surpassed HS10 in colonization competence (Fig. 1A and B) and plant-growth-promoting effect on Jinyou-35 (Tables 9 and 10), which might have offset its deficiency in the ability to produce the enzymes and siderophores.

It has been documented that the plant-growth-promoting effect of some plant-growth-promoting rhizobacteria (PGPR) is positively correlated with their ability to induce systemic disease protection (Murphy et al. 2003; S. Zhang et al. 2004), which involves agerelated resistance (a type of systemic resistance) —older plants have enhanced resistance to pathogens relative to younger ones (Kus et al. 2002). To date, numerous strains in the genera Bacillus and Enterobacter have been identified as PGPR that are associated with the plant rhizosphere, enhance plant resistance to diseases, and promote plant growth (Niu et al. 2011; Xue et al. 2009). In this study, DS22 (B. pumilus), HS10 (B. licheniformis), and DP14 (Enterobacter sp.) successfully colonized the cucumber rhizosphere, significantly suppressed CDM, and promoted plant growth under both greenhouse and field conditions, demonstrating that they are PGPR.

Some PGPR can elicit ISR upon root colonization (van Loon et al. 1998). In the current research, applied as RD, DP14 and HS10 achieved significant efficacy (49.91 to $63.23 \%$ ) at 8 and $15 \mathrm{dpt}$ (Table 4), comparable with the typical reduction in disease symptoms by 40 to $60 \%$ due to ISR expression in plants (van Wees et al. 2000). This suggests that DP14 and HS10 might have the ability to trigger ISR. If this is the case, they may also be effective against various pathogens, including those taxonomically very different from $P$. cubensis, such as $R$. solani, because ISR-eliciting rhizobacteria are considered to have more potential for suppressing a wider range of pathogens than antagonists with antibiosis as the main biocontrol mechanism (Choudhary and Johri 2009). None of these strains had antagonism toward $R$. solani (Table 1). Consistently, in our greenhouse experiment aimed to evaluate their effectiveness against sheath blight of rice (caused by artificial inoculation of $R$. solani to rice sheaths), DP14 and HS10 achieved significant biocontrol efficacy (45.81 to 69.58\%) with RD (C. Gu and G. Wang, unpublished data). 
In line with its assumed potential for eliciting plant systemic resistance, HS10 has recently proved effective against litchi downy blight caused by Peronophythora litchii, which involved its ability to produce volatile organic compounds that induced plant systemic defense responses such as increased activities of the defense enzymes phenylalanine ammonia lyase (PAL) and polyphenol oxidase (PPO) (L.
Zheng, unpublished data). Interestingly, Sen et al. (2014) also found that PAL and PPO activities were increased in leaves of cucumber plants treated with three PGPR strains-namely, Achromobacter sp. (F2feb.44), Streptomyces sp. Zapt10, and B. licheniformis AE6-which corresponded to their effects of inducing systemic resistance to $P$. cubensis in cucumber and improving cucumber fruit yield in field

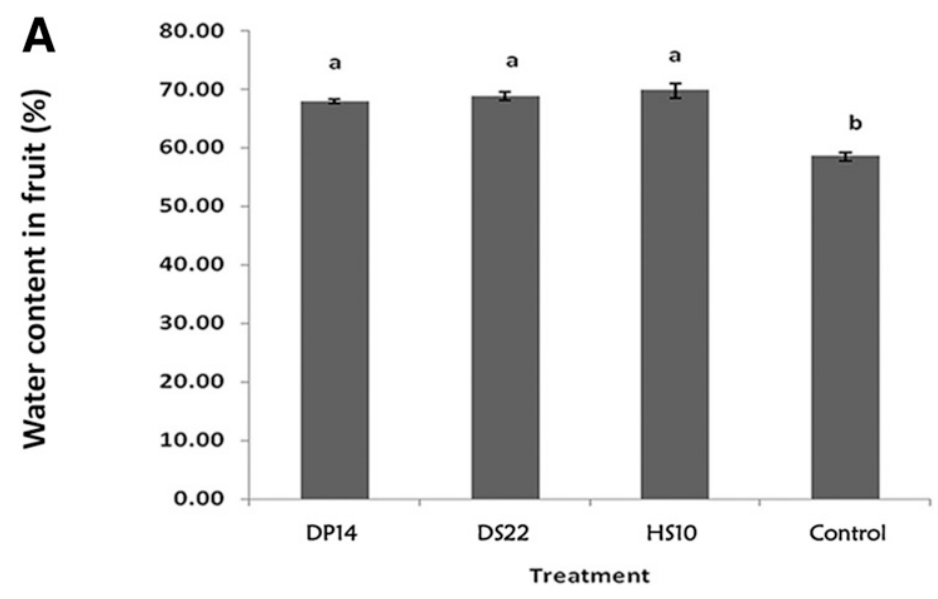

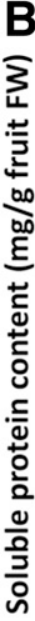
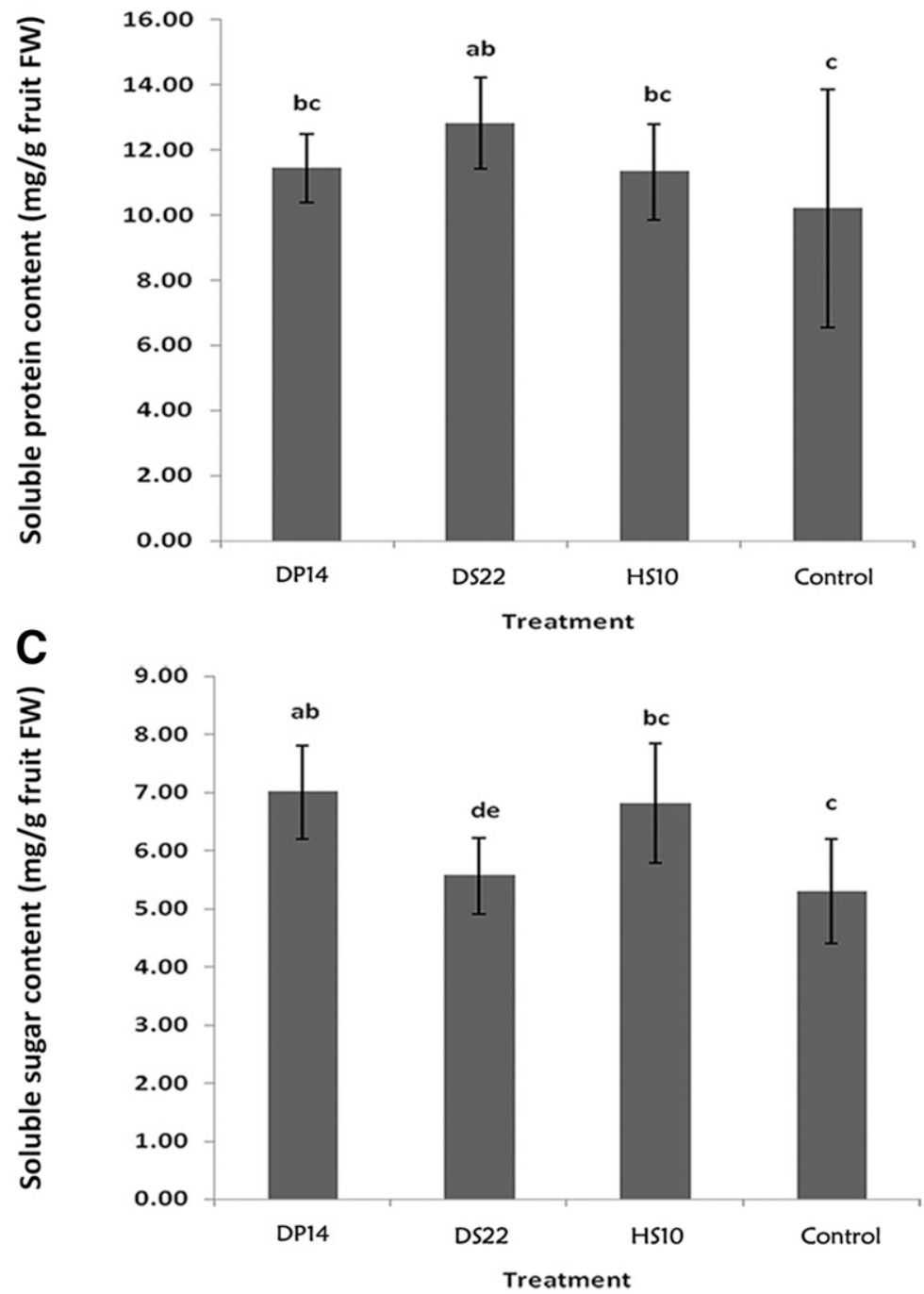

Fig. 2. Effect of DP14, DS22, and HS10 on nutrient contents in cucumber fruit under field conditions. Cucumber fruit was sampled at 30 days post first bacterial treatment for determining the contents of A, water; $B$, soluble protein; C, soluble sugar; $D, V$; and $E$, free amino acids. Data are presented as means of four replicates \pm standard errors; values with the same lowercase letter within the same column do not differ significantly according to a least significant difference test at $P<0.05$. 
trials. Based on the two lines of evidence, we infer that the efficacy of HS10 against CDM in FT 2010 and FT 2011 might also involve enhancing activities of PAL and PPO in cucumber.

In 2-year field trials, the overall efficacy of HS10, DP14, and DS22 relative to that of propamocarb was 106.25 to $117.17 \%$ with FS+RD but only 70.98 to $84.03 \%$ with FS (Table 8), indicating that the former is more effective than the latter in enabling these strains to fully exert biocontrol activity. This can be explained by the fact that these strains have different mechanisms of action in leaves and roots and that applying them to both tissues allowed the combination of various mechanisms upon their colonization, thereby producing an additive protective effect compared with that due to FS alone. Their biocontrol mechanisms include leaf and root colonization, production of extracellular hydrolytic enzymes and siderophores, and activation of plant systemic resistance that might involve ISR and age-related resistance due to their plant-growth-promoting effect. For PGPR, their colonization of plant rhizosphere is essential for them to sufficiently exert growth-promoting effect. In addition to RD, seed treatment (ST) also results in PGPR colonizing rhizosphere (Vidhyasekaran and Muthamilan 1995). In the greenhouse experiment conducted by S. M. Zhang et al. (2004), treatments with B. subtilis ZH-8 as FS alone and as ST plus FS (ST+FS) both significantly suppressed CDM on cucumber relative to the nontreated control, and this strain achieved higher biocontrol efficacy (75.61\%) with ST+FS than with FS (69.49\%); however, their difference was statistically insignificant. On the other hand, cucumber plants treated with ST+FS were more robust, with darker green leaves compared with those treated with FS, demonstrating that ST+FS is more effective in eliciting the plant-growth-promoting effect of B. subtilis ZH-8 than FS alone. Like FS+RD used in our study, ST+FS also enables PGPR to sufficiently utilize their multiple biocontrol mechanisms in leaves and roots; in the aforementioned study by Sen et al. (2014), PGPR strains-namely, Achromobacter sp. (F2feb.44), Streptomyces sp. Zapt10, and B. licheniformis AE6were applied as ST+FS to boost their efficacy against CDM by combining their various pathogen-suppressive mechanisms, including elicitation of ISR and production of antibiotics and cellwall-degrading enzymes.

In addition, DP14 and HS10 showed in vitro antagonism toward $P$. ultimum and $P$. capsici, respectively (Table 1), indicating that they have the mechanism of antibiosis. Taking into account the close

Fig. 2. (Continued from previous page)
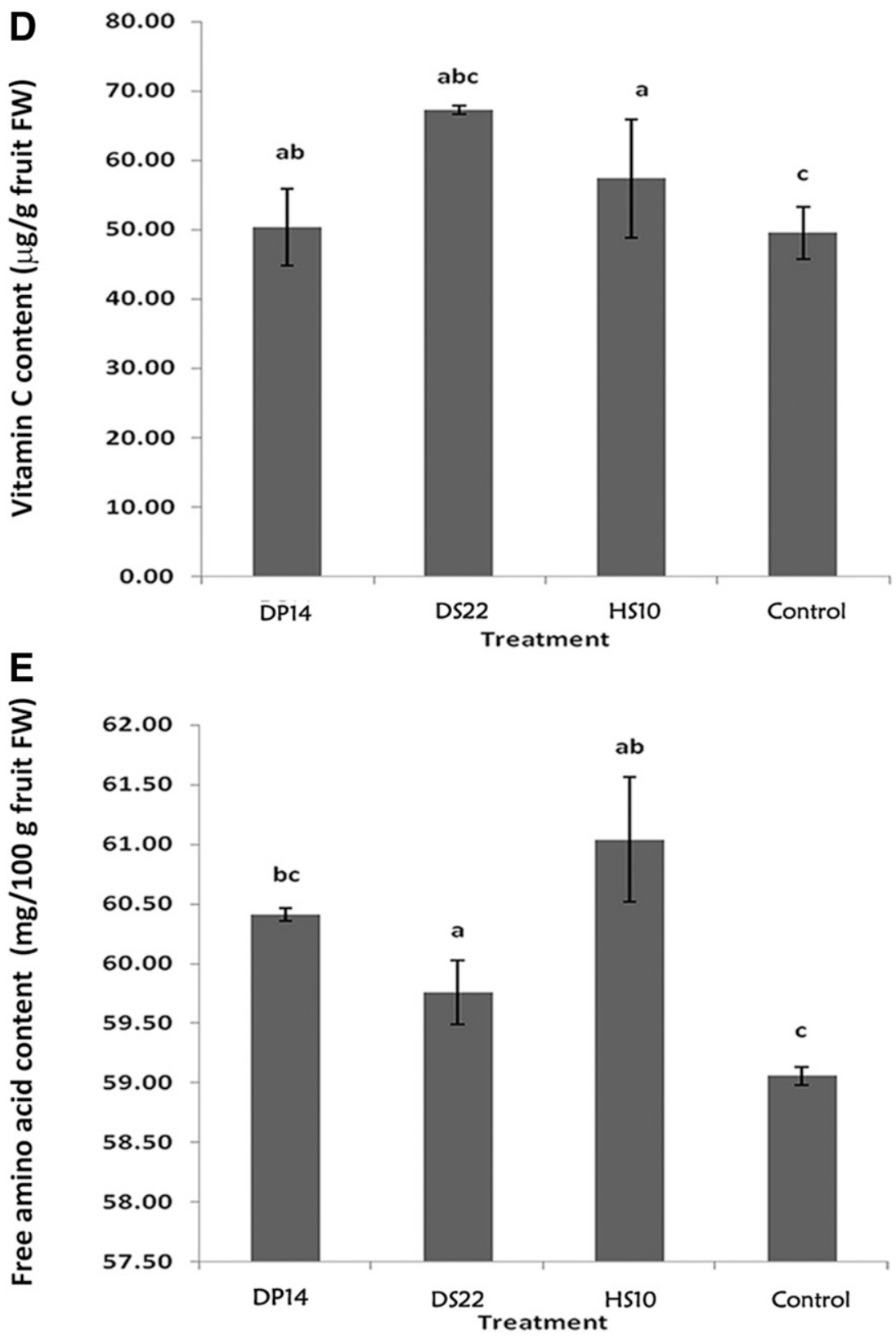
evolutionary relationship of the two pathogens with $P$. cubensis, DP14 and HS10 might have antagonism against P. cubensis, which, however, needs to be clarified in future study.

In the present study, PGPR DP14, DS22, and HS10 were consistently effective in controlling CDM in 2-year field trials in Huai' an City. The consistency in the performance of these strains, as well as HP4, was also demonstrated in a 2013 field trial in Taicang City (Taicang and Huai'an are located in south and north of the Yangtze River, respectively, with a distance of about $380 \mathrm{~km}$ between them and significantly different soil and climate conditions). In this trial, DP14, DS22, HS10, and HP4 applied as FS+RD significantly suppressed naturally occurring CDM on a different cucumber cultivar, Shenqing 1; and also significantly increased its yield (C. Gu and G. Wang, unpublished data).

The above four antagonistic bacteria were selected from the mixed rhizosphere and surrounding bulk soils (DS 22 and HS10) and the phyllosphere (DP14 and HP4) of healthy and diseased cucumber plants, indicating that these microenvironments are good sources of potential BCAs. Furthermore, the ability to produce extracellular hydrolytic enzymes and siderophores is only part of the biocontrol mechanisms of BCA. To streamline screens for future BCAs, biocontrol assays should include not only isolates strong in this ability (such as HS10) but also those weak in it (such as DP14), because the latter might have strong colonization competence, plant-growth-promoting effect, or capacity to induce plant systemic resistance, which could make them promising BCAs.

In conclusion, Enterobacteriaceae DP14, B. pumilus DS22, and B. licheniformis HS10 are PGPR strains with significant field efficacy in controlling CDM. Their biocontrol efficacy and consistency can be improved by applying them to both cucumber roots and leaves compared with only to the leaves; the combinative application method allows them to combine their various mechanisms of action in the leaves and roots, including their plant-growth promoting effect. In a future study, we will evaluate the potential of DP14 and HS10 for eliciting ISR, which would be useful for developing sustainable management approaches to CDM and improving cucumber yield while minimizing the use of perilous chemical fungicides.

\section{Acknowledgments}

We thank H.-X. Liu and Y.-P. Wang at Nanjing Agriculture University for their valuable suggestions on the manuscript; D.-D. Niu at Nanjing Agricultural University for his useful comments; Dr. W. Yang at Huai' an Normal University for his help on data analysis; Y. Huang, G. Feng, J.-J. Cao, and Q. Wang at Huai' an Normal University for their assistance in field trials; and Y.-Z. Ding at the town of Dingji in Huai'an City for his work in field management.

\section{Literature Cited}

Alabouvette, C., Olivain, C., Migheli, Q., and Steinberg, C. 2009. Microbiological control of soil-borne phytopathogenic fungi with special emphasis on wiltinducing Fusarium oxysporum. New Phytol. 184:529-544.

Berg, G., Fritze, A., Roskot, N., and Smalla, K. 2001. Evaluation of potential biocontrol rhizobacteria from different host plants of Verticillium dahliae Kleb. J. Appl. Microbiol. 91:963-971.

Call, A. D., Wehner, T. C., Holmes, G. J., and Ojiambo, P. S. 2013. Effects of host plant resistance and fungicides on severity of cucumber downy mildew. HortScience 48:53-59.

Choudhary, D. K., and Johri, B. N. 2009. Interactions of Bacillus spp. and plants-With special reference to induced systemic resistance (ISR). Microbiol. Res. 164:493-513.

Cohen, Y., and Reuveni, Y. 1983. Competition between metalaxyl-resistant and sensitive strains of Pseudoperonosporo cubensis on cucumber plants. Phytopathology 73:1516-1520.

Cohen, Y., Van den Langenberg, K. M., Wehner, T. C., Ojiambo, P. S., Hausbeck, M., Quesada-Ocampo, L. M., Lebeda, A., Sierotzki, H., and Gisi, U. 2015. Resurgence of Pseudoperonospora cubensis: the causal agent of cucurbit downy mildew. Phytopathology 105:998-1012.

Dahiya, N., Tewari, R., Tiwari, R. P., and Hoondal, G. S. 2005. Production of an antifungal chitinase from Enterobacter sp. NRG4 and its application in protoplast production. World J. Microbiol. Biotechnol. 21:1611-1616.

El-Gremi, S. M. A., Ghoniem, K. E., Mohamed, H. A., and Kamel, S. M. H. 2013. Mode of action of Bacillus pumilus in suppressing Pseudoperonospora cubensis (Berk and Curt) Rostow, the pathogen of downy mildew of cucumber. Egypt. J. Pest Control 23:71-77.

Faheem, M., Raza, W., Zhong, W., Nan, Z., Shen, Q. R., and Xu, Y. C. 2015. Evaluation of the biocontrol potential of Streptomyces goshikiensis YCXU against Fusarium oxysporum f. sp. niveum. Biol. Control 81:101-110.
Fravel, D. R. 1988. Role of antibiosis in the biocontrol of plant diseases. Annu. Rev. Phytopathol. 26:75-91.

Georgieva, O. A., and Georgiev, G. A. 2009. Biological control of diseases on main vegetables-researches and practice in Marista Vegetable Crops Institute. Acta Hortic. 830:511-518.

Ghose, T. K. 1987. Measurement of cellulase activities. Pure Appl. Chem. 59: 257-268.

Guo, J. H., Qi, H. Y., Guo, Y. H., Ge, H. L., Gong, L. Y., Zhang, L. X., and Sun, P. H. 2004. Biocontrol of tomato wilt by plant growth-promoting rhizobacteria. Biol. Control 29:66-72.

Haas, D., and Keel, C. 2003. Regulation of antibiotic production in root colonizing Pseudomonas spp. and relevance for biological control of plant disease. Annu. Rev. Phytopathol. 41:117-153.

Haggag, W. M. 2002. Application of epidermal coating antitranspirants for controlling cucumber downy mildew in greenhouse. Plant Pathol. Bull. 11:69-78.

Han, Y. S. 1996. Food Chemistry Experiment Guide. China Agricultural University Press, Beijing (in Chinese).

Harish, S., Saravanakumar, D., Radjacommare, R., Ebenezar, E. G., and Seetharaman, K. 2008. Use of plant extracts and biocontrol agents for the management of brown spot disease in rice. BioControl 53:555-567.

Keinath, A. P., Holmesb, G. J., Evertsc, K. L., Egeld, D. S., and Langston, D. B., Jr. 2007. Evaluation of combinations of chlorothalonil with azoxystrobin, harpin, and disease forecasting for control of downy mildew and gummy stem blight on melon. Crop Prot. 26:83-88.

Kloepper, J. W., Leong, J., Teintze, M., and Schroth, M. N. 1980. Enhanced plant growth by siderophores produced by plant growth-promoting rhizobacteria Nature 286:885-886.

Koch, E. 1999. Evaluation of commercial products for microbial control of soilborne plant diseases. Crop Prot. 18:119-125.

Kus, J. V., Zaton, K., Sarkar, R., and Cameron, R. K. 2002. Age-related resistance in Arabidopsis is a developmentally regulated defense responses to Pseudomonas syringae. Plant Cell 14:479-490.

Lorito, M., Harman, G. E., Hayes, C. K., Broadway, R. M., Tronsmo, A., Woo, S. L., and Di Pietro, A. 1993. Chitinolytic enzymes produced by Trichoderma harzianum: antifungal activity of purified endochitinase and chitobiosidase. Phytopathology 83:302-307.

Morris, S. J., Zink, T., Conners, K., and Allen, M. F. 1997. Comparison between fluorescein diacetate and differential fluorescent staining procedures for determining fungal biomass in soils. Appl. Soil Ecol. 6:161-167.

Murphy, J. F., Reddy, M. S., Ryu, C. M., Kloepper, J. W., and Li, R. 2003. Rhizobacteria-mediated growth promotion of tomato leads to protection against Cucumber mosaic virus. Phytopathology 93:1301-1307.

Nautiyal, C. S. 1997. Rhizosphere competence of Pseudomonas sp. NBRI9926 and Rhizobium sp. NBRI9513 involved in the suppression of chickpea (Cicerarietinum L.) pathogenic fungi. FEMS Microbiol. Ecol. 23:145-158.

Niu, D. D., Liu, H. X., Jiang, C. H., Wang, Y. P., Wang, Q. Y., Jin, H. L., and Guo, J. H. 2011. The plant growth-promoting rhizobacterium Bacillius cereus AR156 induces systemic resistance in Arabidopsis thaliana by simultaneously activating salicylate- and jasmonate/ethylene-dependent signaling pathways. Mol. Plant-Microbe Interact. 24:533-542.

Okuno, T., Nakayama, M., Okajima, N., and Furusawa, I. 1991. Systemic resistance to downy mildew and appearance of acid soluble proteins in cucumber leaves treated with biotic and biotic inducers. Jpn. J. Phytopathol. 57: 203-211.

Priyanka, A. T., Kotasthane, A. S., Kosharia, A., Kushwah, R., Zaidi, N. W., and Singh, U. S. 2017. Crop specific plant growth promoting effects of ACCd enzyme and siderophore producing and cynogenic fluorescent Pseudomonas. 3 Biotechnol. 7:27.

Rademaker, J. L. W., and De Bruijn, F. J. 1997. Characterization and classification of microbes by REP-PCR genomic fingerprinting and computer-assisted pattern analysis. Pages 1-26 in: DNA Markers: Protocols, Applications and Overviews. G. Caetano-Anollés and P. M. Gresshoff, eds. Wiley and Sons, New York.

Reuveni, R. 1983. Resistance reactions of Cucumis melo to inoculation with Pseudoperonospora cubensis. Ann. Appl. Biol. 102:533-537.

Roberts, W. K., and Selitrennikoff, C. P. 1988. Plant and bacterial chitinases differ in antifungal activity. J. Gen. Microbiol. 134:169-176.

Ryu, C. M., Farag, M. A., Hu, C.-H., Reddy, M. S., Hu, C.-H., Reddy, M. S., Kloepper, J. W., and Paré, P. W. 2004. Bacterial volatiles induce systemic resistance in Arabidopsis. Plant Physiol. 134:1017-1026.

Sen, K., Sengupta, C., and Saha, J. 2014. PGPR consortium in alleviating downy mildew of cucumber. International Journal of Plant. Anim. Environ. Sci. 4:150-159.

Shin, S. H., Lim, Y., Lee, S. E., Yang, N. W., and Rhee, J. H. 2001. CAS agar diffusion assay for the measurement of siderophores in biological fluids. J. Microbiol. Methods 44:89-95.

Shishido, M., Miwa, C., Usami, T., Amemiya, Y., and Johnson, K. B. 2005 Biological control efficiency of fusarium wilt of tomato by nonpathogenic Fusarium oxysporum Fo-B2 in different environments. Phytopathology 95: $1072-1080$

Silva, E. A. D., Mazzafera, P., Brunini, O., Sakai, E., Arruda, F. B., Mattoso, L. H. C., Carvalho, C. R. L., and Pires, R. C. M. 2005. The influence of water management and environmental conditions on the chemical composition and beverage quality of coffee beans. Brazil. J. Plant Physiol. 17:229-238. 
Thomashow, L. S., and Weller, D. M. 1988. Role of a phenazine antibiotic from Pseudomonas fluorescensin biological control of Gaeumannomyces graminis var. tritici. J. Bacteriol. 170:3499-3508.

van Loon, L. C., Bakker, P. A. H. M., and Pieterse, C. M. J. 1998. Systemic resistance induced by rhizosphere bacteria. Annu. Rev. Phytopathol. 36:453-483.

van Wees, S. C. M., de Swart, E. A. M., van Pelt, J. A., van Loon, L. C., and Pieterse, C. M. J. 2000. Enhancement of induced disease resistance by simultaneous activation of salicylate- and jasmonate-dependent defense pathways in Arabidopsis thaliana. Proc. Natl. Acad. Sci. USA 97:8711-8716.

Vidhyasekaran, P., and Muthamilan, M. 1995. Development of formulations Pseudomonas fluorescens for control of chick pea wilt. Plant Dis. 79: 782-786.

Wang, C. J., Yang, W., Wang, C., Gu, C., Niu, D. D., Liu, H. X., Wang, Y. P., and Guo, J. H. 2013. Induction of drought tolerance in cucumber plants by a consortium of three plant growth-promoting rhizobacterium strains. PLoS One $7: 1-10$.

Winterscheidt, H., Minassian, V., and Weltzien, H. C. 1990. Studies on biological control of cucumber downy mildew-(Pseudoperonospora cubensis (Berk. et Curt.) Rost)—with compost extracts. Gesunde Pflanz. 42:235-238.
Xue, Q. Y., Chen, Y., Li, S. M., Chen, L. F., Ding, G. C., Guo, D. W., and Guo, J. H. 2009. Evaluation of the strains of Acinetobacter and Enterobacter as potential biocontrol agents against Ralstonia wilt of tomato. Biol. Control 48:252-258.

Yang, H. F., Chen, S. Q., and Wang, T. Z. 1994. The methods of applying a biological control agent Bacillus licheniformis. Patent. CN93100172.2.

Yang, J. H., Liu, H. X., Zhu, G. M., Pan, Y. L., Xu, L. P., and Guo, J. H. 2008. Diversity analysis of antagonists from rice-associated bacteria and their application in biocontrol of rice diseases. J. Appl. Microbiol. 104:91-104.

Yang, M. M., Mavrodi, D. V., Mavrodi, O. V., Bonsall, R. F., Parejko, J. A. Paulitz, T. C., Thomashow, L. S., Yang, H. T., Weller, D. M., and Guo, J. H. 2011. Biological control of take-all by fluorescent Pseudomonas spp. from Chinese wheat fields. Phytopathology 101:1481-1491.

Zhang, S., Reddy, M. S., and Kloepper, J. W. 2004. Tobacco growth enhancement and blue mold disease protection by rhizobacteria: Relationship between plan growth promotion and systemic disease protection by PGPR strain 90-166. Plant Soil 262:277-288.

Zhang, S. M., Sha, C. Q., Wang, Y. X., Li, J., Wang, J. L., Zhao, X. Y., and Li, J. P. 2004. Study on the efficacy of Bacillus subtilis ZH-8 against cucumber downy mildew. Biotechnology (Faisalabad) 14:56-57 (in Chinese). 